\title{
Geochemistry of hydrothermal fluids from the eastern sector of the Sabatini Volcanic District (central Italy)
}

\author{
D. Cinti ${ }^{\text {a, }}{ }^{*}$, F. Tassi $^{\text {b, d }}{ }^{\text {, M. Procesi }}{ }^{\text {a }}$, L. Brusca ${ }^{\text {c }}$, J. Cabassi ${ }^{\text {b, d }}$, F. Capecchiacci ${ }^{\text {b, d }}$, \\ A. Delgado Huertas ${ }^{\text {e, G. Galli }}{ }^{\text {a }}$, F. Grassa ${ }^{\text {c }}$, O. Vaselli ${ }^{\text {b, d }}$, N. Voltattorni ${ }^{\text {a }}$ \\ a Istituto Nazionale di Geofisica e Vulcanologia (INGV), via di Vigna Murata 605, 00143 Roma, Italy \\ b Dipartimento di Scienze della Terra, Università di Firenze, via G. La Pira 4, 50121 Firenze, Italy \\ c Istituto Nazionale di Geofisica e Vulcanologia (INGV), via Ugo La Malfa 153, 90146 Palermo, Italy \\ ${ }^{\mathrm{d}}$ CNR - Istituto di Geoscienze e Georisorse, via G. La Pira 4, 50121 Firenze, Italy \\ e Instituto Andaluz de Ciencas de la Tierra IACT (CSIC-UGR), avenida de las Palmas 4, 18100 Armilla, Granada, Spain
}

\section{A R T I C L E I N F O}

\section{Article history:}

Received 4 April 2017

Received in revised form

23 June 2017

Accepted 27 June 2017

Available online 28 June 2017

Handling Editor: Elisa Sacchi

\section{Keywords:}

Fluid geochemistry

Central Italy

Water-gas-rock interaction

Geothermometry

Sabatini Volcanic District

\begin{abstract}
A B S T R A C $T$
This study reports a complete geochemical dataset of 215 water and 9 gas samples collected in 2015 from thermal and cold discharges located in the eastern sector of the Sabatini Volcanic District (SVD), Italy. Based on these data, two main aquifers were recognized, as follows: 1) a cold $\mathrm{Ca}-\mathrm{HCO}_{3}$ to $\mathrm{Ca}(\mathrm{Na})-\mathrm{HCO}{ }_{3}$ aquifer related to a shallow circuit within Pliocene-Pleistocene volcanic and sedimentary formations and 2) a deep $\mathrm{CO}_{2}$-pressurized aquifer hosted in Mesozoic carbonate-evaporitic rocks characterized by a Ca$\mathrm{HCO}_{3}\left(\mathrm{SO}_{4}\right)$ to $\mathrm{Na}(\mathrm{Ca})-\mathrm{HCO}_{3}(\mathrm{Cl})$ composition. A thick sequence of low-permeability formations represents a physical barrier between the two reservoirs. Interaction of the $\mathrm{CO}_{2}$-rich gas phase with the shallow aquifer, locally producing high-TDS and low-pH cold waters, is controlled by fractures and faults related to buried horst-graben structures. The $\delta^{18} \mathrm{O}-\mathrm{H}_{2} \mathrm{O}$ and $\delta \mathrm{D}-\mathrm{H}_{2} \mathrm{O}$ values indicate meteoric water as the main source for both the shallow and deep reservoirs. Carbon dioxide, which is characterized by $\delta^{13} \mathrm{C}_{-} \mathrm{CO}_{2}$ values ranging from -4.7 to $+1.0 \%$ V-PDB, is mostly produced by thermo-metamorphic decarbonation involving Mesozoic rock formations, masking possible $\mathrm{CO}_{2}$ contribution from mantle degassing. The relatively low $R / R_{a}$ values (0.07-1.04) indicate dominant crustal He, with a minor mantle He contribution. The $\mathrm{CO}_{2} /{ }^{3} \mathrm{He}$ ratios, up to $6 \times 10^{12}$, support a dominant crustal source for these two gases. The $\delta^{34} \mathrm{~S}$ $\mathrm{H}_{2} \mathrm{~S}$ values (from +9.3 to $+11.3 \%$ o $\mathrm{V}$-CDT) suggests that $\mathrm{H}_{2} \mathrm{~S}$ is mainly related to thermogenic reduction of Triassic anhydrites. The $\delta^{13} \mathrm{C}_{-} \mathrm{CH}_{4}$ and $\delta \mathrm{D}-\mathrm{CH}_{4}$ values (from -33.4 to $-24.9 \%$ V-PDB and from -168 to $-140 \% \mathrm{~V}$-SMOW, respectively) and the relatively low $\mathrm{C}_{1} / \mathrm{C}_{2}$ ratios $(<100)$ are indicative of a prevailing $\mathrm{CH}_{4}$ production through thermogenic degradation of organic matter. The low $\mathrm{N}_{2} / \mathrm{Ar}$ and high $\mathrm{N}_{2} /$ He ratios, as well as the ${ }^{40} \mathrm{Ar} /{ }^{36} \mathrm{Ar}$ ratios $(<305)$ close to atmospheric ratio, suggest that both $\mathrm{N}_{2}$ and $\mathrm{Ar}$ mostly derive from air. Notwithstanding, the positive $\delta^{15} \mathrm{~N}-\mathrm{N}_{2}$ values (from +0.91 to $+3.7 \%$ NBS air) point to a significant extra-atmospheric $\mathrm{N}_{2}$ contribution. Gas geothermometry in the $\mathrm{CH}_{4}-\mathrm{CO}_{2}-\mathrm{H}_{2}$ and $\mathrm{H}_{2} \mathrm{~S}-\mathrm{CO}_{2}-\mathrm{H}_{2}$ systems indicate equilibrium temperatures $<200^{\circ} \mathrm{C}$, i.e. lower than those measured in deep geothermal wells $\left(\sim 300^{\circ} \mathrm{C}\right)$, due to either an incomplete attainment of the chemical equilibria or secondary processes (dilution and/or scrubbing) affecting the chemistry of the uprising fluids. Although the highly saline $\mathrm{Na}-\mathrm{Cl}$ fluids discharged from the explorative geothermal wells in the study area support the occurrence of a well-developed hydrothermal reservoir suitable for direct exploitation, the chemistry of the fluid discharges highlights that the uprising hydrothermal fluids are efficiently cooled and diluted by the meteoric water recharge from the nearby Apennine sedimentary belt. This explains the different chemical and isotopic features shown by the fluids from the eastern and western sectors of SVD, respectively, the latter being influenced by this process at a lesser extent. Direct uses may be considered a valid alternative for the exploitation of this resource.
\end{abstract}

๑ 2017 Elsevier Ltd. All rights reserved.

\footnotetext{
* Corresponding author.

E-mail address: daniele.cinti@ingv.it (D. Cinti).
} 


\section{Introduction}

The Sabatini Volcanic District (SVD) is part of the periTyrrhenian sector of central Italy, an area characterized by a complex geodynamic setting that, during the Neogene, produced NNWSSE oriented horst-graben structures, alkaline magmatism, and a widespread thermal anomaly (Barberi et al., 1994, Fig. 1). In this region, mantle degassing and thermo-metamorphic processes feed a regional pressurized gas system (e.g., Chiodini et al., 1999; Minissale, 2004) that is connected to $\mathrm{CO}_{2}$-rich thermal and cold fluid discharges through fractures and faults related to an extensional tectonic regime (Barberi et al., 1994), producing a number of $\mathrm{CO}_{2}$-rich thermal and cold fluid discharges.

In the framework of exploration surveys carried out in the past
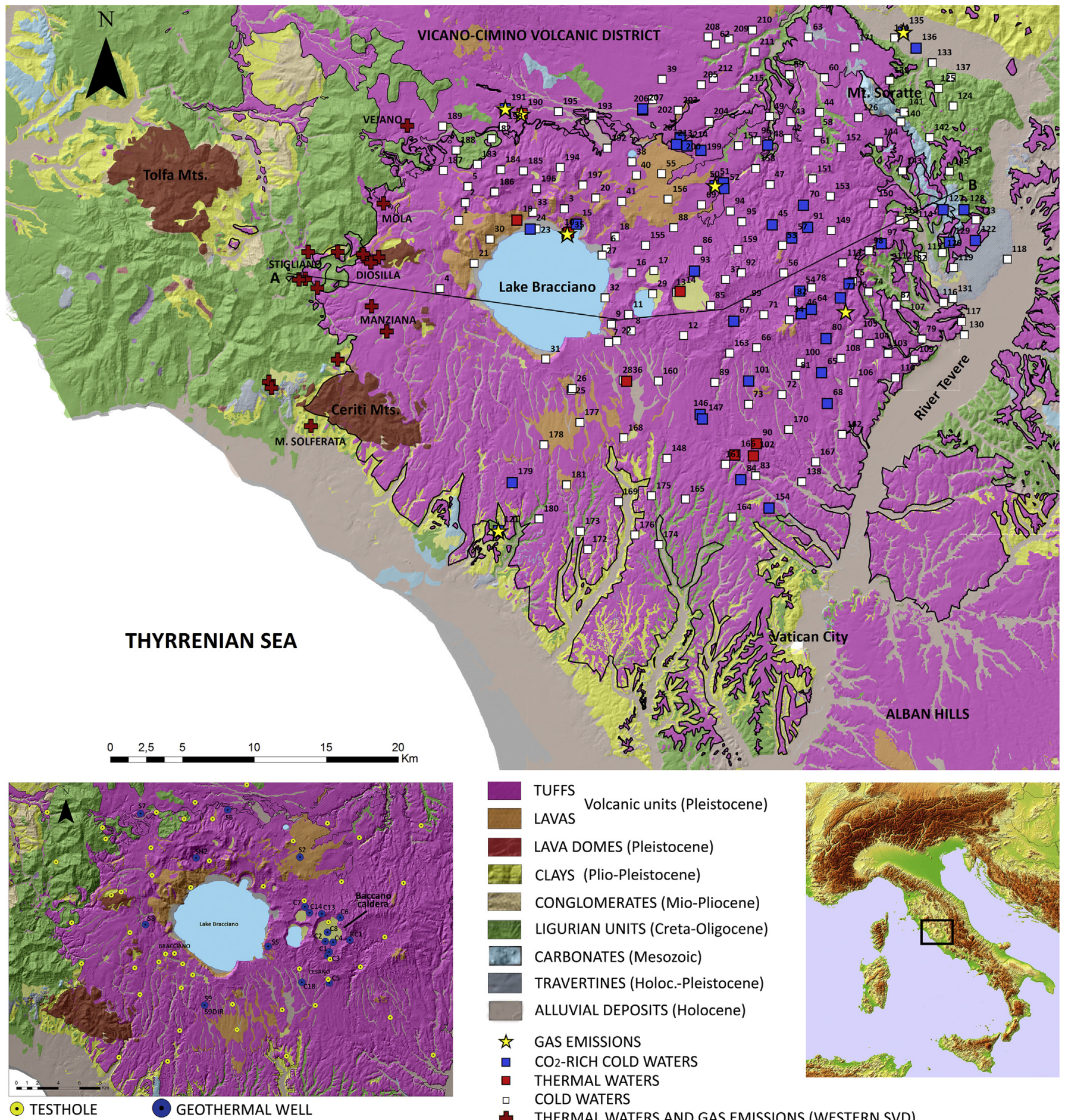

TUFFS

LAVAS

LAVA DOMES (Pleistocene)

CLAYS (Plio-Pleistocene)

CONGLOMERATES (Mio-Pliocene)

LIGURIAN UNITS (Creta-Oligocene)

CARBONATES (Mesozoic)

TRAVERTINES (Holoc.-Pleistocene) ALLUVIAL DEPOSITS (Holocene)

GASEMISSIONS

- $\mathrm{CO}_{2}$-RICH COLD WATERS

- THERMAL WATERS

口 COLD WATERS

4 THERMAL WATERS AND GAS EMISSIONS (WESTERN SVD)

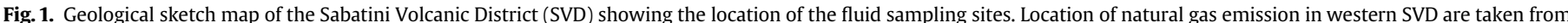

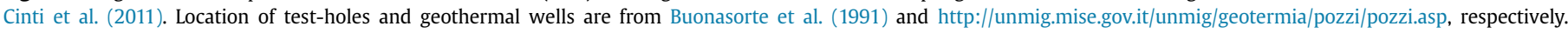
Interpretative section corresponding to trace A-B is reported in Fig. 14. 
decades for geothermal exploitation purposes (Calamai et al., 1976; Funiciello et al., 1979; Allegrini et al., 1982; Cavarretta and Tecce, 1987; Buonasorte et al., 1995), a high enthalpy geothermal field was recognized in the eastern SVD (i.e. Cesano field; Calamai et al., 1976). Explorative wells (from 960 to $3200 \mathrm{~m}$ depth) were drilled within the Baccano Caldera (Fig. 1; Funiciello et al., 1979), where a maximum temperature of $\sim 300{ }^{\circ} \mathrm{C}$ was measured (Allegrini et al., 1982). Potentially productive wells (C1, C5, C7, C8), having an average depth of $\sim 1750 \mathrm{~m}$ and bottom-hole temperatures ranging from 141 to $221{ }^{\circ} \mathrm{C}$, discharged a highly saline (up to $350 \mathrm{~g} / \mathrm{L}$ ) brine associated with a $\mathrm{CO}_{2}$-dominated gas phase (Calamai et al., 1976). Due to the high salinity of the liquid phase and the relatively high concentrations of corrosive gases $\left(\mathrm{H}_{2} \mathrm{~S}\right)$, these wells were considered not economically exploitable and then abandoned (Billi et al., 1986). Few years later, the geothermal exploration resumed in this area and new wells were drilled outside the Baccano Caldera (Fig. 1; Cavarretta and Tecce, 1987; Buonasorte et al., 1991, 1995). Among them, 8 wells (from 1390 to $3886 \mathrm{~m}$ depth) were drilled within the SVD, where bottom-hole temperatures up to $300{ }^{\circ} \mathrm{C}$ were measured. Nevertheless, the hydrothermal resource was not considered economically exploitable. Notwithstanding these negative attempts, Italy is recently experiencing a renewed interest for geothermal energy, favoured by new technological advances, encouraged by the growth of energy demand and the need to reduce $\mathrm{CO}_{2}$ emissions to the atmosphere (Procesi et al., 2013). Presently, in the Latium region new research concessions have already been conferred, whereas private companies are claiming other areas for geothermal prospecting purposes (http://unmig. mise.gov.it/unmig/geotermia/titoli/titoli.asp). This provided a new pulse for developing geochemical investigations on thermal fluid discharges in central Italy, including the SVD.

The main geochemical features of the thermal discharges in central Italy were discussed in several studies carried out since the 1970's (e.g., Baldi et al., 1973; Dall'Aglio et al., 1994; Duchi and Minissale, 1995; Chiodini et al., 1999; Minissale et al., 1997a; Minissale, 2004). On a local scale, a geochemical study focusing on the western sector of the SVD (Cinti et al., 2011) reported a detailed chemical and isotopic dataset, which allowed to construct a conceptual model aimed to describe the hydrothermal fluid circulation. In 2015, following a similar approach, the geochemical investigation was extended to fluid discharges from the eastern SVD (Fig. 1). A similar detailed approach was adopted in the present study to complete the description of the hydrothermal fluid circulation related to this volcanic complex. Up to 215 waters and 9 bubbling gases (Fig. 1) were collected and analyzed for determining the composition of the main and trace components and the stable isotopes of water, $\mathrm{CO}_{2}$ and $\mathrm{CH}_{4}$, noble gases (He and $\mathrm{Ar}$ ), $\mathrm{N}_{2}$, and sulfur in $\mathrm{H}_{2} \mathrm{~S}$. The main goals were to: $i$ ) investigate the fluid sources and the main chemical-physical processes controlling fluid chemistry, ii) propose a conceptual model to describe the circulation pattern and the processes controlling the chemistry of the thermal fluids, and iii) provide insights into the most promising areas for geothermal exploitation. For these goals, the available stratigraphic, structural, and hydrogeological data were also used.

\section{Geological, structural and hydrological setting}

The $\sim 1000 \mathrm{~km}^{2}$ wide study area is located along the periTyrrhenian sector of central Italy (Fig. 1). In this region, a postcollisional tectonic activity occurred during the Neogene, generating dominantly extensional NNW-SSE-trending fault systems (Barberi et al., 1994) and minor NE-SW-trending transtensive structures that accommodated differential extension (Acocella and Funiciello, 2006). The progressive eastward migration of the extension wave produced a strong crustal thinning $(<25 \mathrm{~km}$;
Scrocca et al., 2003), high heat flow (locally $>200 \mathrm{~mW} / \mathrm{m}^{2}$; Della Vedova et al., 1984; Barberi et al., 1994), and subduction-related magmatism (Peccerillo, 1985; Barberi et al., 1994; Doglioni et al., 1999). Volcanic complexes grew up on buried horst-graben structures, as shown by gravimetric anomalies (Barberi et al., 1994), whilst marine clastic sediments were filled the structural lows.

The SVD was active from 0.60 to 0.08 Ma (Cioni et al., 1993; De Rita et al., 1996; Karner et al., 2001) and consisted of rhyolites, rhyodacites and trachidacites found as dome complexes (Cimarelli and De Rita, 2006), pertaining to the Tuscan Magmatic Province, and under-saturated alkali-potassic pyroclastic and phreatomagmatic deposits with subordinate volumes of lavas related to the Roman Magmatic Province. The early stage of the volcanic activity (0.6-0.4 Ma), mostly consisting of explosive events, occurred from craters located in the eastern and southern sectors of the SVD, while the main explosive phase $(0.3 \mathrm{Ma})$, producing calderaforming pyroclastic flows and several small scoria cones and tuff rings, took place north of the Bracciano volcano-tectonic depression. During the latest eruptive phase $(0.17-0.08 \mathrm{Ma})$ hydromagmatic products were ejected from N-S and E-W-oriented craters located along the eastern margin of Lake Bracciano.

The volcanic products overly a tectono-stratigraphic sequence consisting of (from top to bottom): 1) a Plio-Pleistocene complex, including conglomerates, sandstones and clays, 2) CretaceousOligocene (?) Ligurian and sub-Ligurian units (Ligurian s.l.), including calcareous-pelitic calcarenites and arenaceous-pelitic turbidites (Fazzini et al., 1972), 3) Mesozoic carbonates, and 4) Triassic evaporites (Burano Fm.).

The hydrogeological setting is dominated by a regional hydrothermal reservoir hosted in the carbonate-evaporite units and a shallow, mainly unconfined, regional aquifer within the volcanic rocks (Capelli et al., 2005). Low-permeability Plio-Pleistocene deposits and/or the Ligurian s.l. rocks act as an efficient impervious barrier between the shallow and the deep aquifer. Locally, permeable layers within the low-permeability sedimentary deposits host perched aquifers that feed numerous springs of limited and discontinuous extent (Dall'Aglio et al., 1994). The Bracciano Lake represents the outcrop of the shallow volcanic aquifer. Three piezometric highs, identified near the Bracciano Lake (Capelli et al., 2005), force groundwater to flow towards the Tevere River to the E, the Tolfa Mountains to the $\mathrm{W}$ and the lake itself, respectively (Fig. 1).

\section{Methods}

Water samples were collected from cold and thermal springs, occasionally showing bubbling gases, as well as municipal and domestic wells. The chemical and isotopic dataset also includes published data (Cinti et al., 2014) of 34 waters and 4 bubbling gases (samples 190, 191, 201, 216) located at the border between the SVD and the Vicano-Cimino Volcanic District. The field and laboratory analytical results are listed in Table 1 and as supplementary material (Tables $1 \mathrm{~S}$ and $2 \mathrm{~S}$ ).

\subsection{Groundwater sampling and analysis}

Temperature, $\mathrm{pH}, \mathrm{Eh}$, electrical conductivity and alkalinity concentrations (acidimetric titration with $0.05 \mathrm{~N} \mathrm{HCl}$ ) concentrations were determined in situ. One filtered $(0.45 \mu \mathrm{m})$ and two filtered and acidified (with ultra-pure $\mathrm{HCl}$ and $\mathrm{HNO}_{3}$, respectively) aliquots were collected and stored in high-density polyethylene bottles for laboratory analysis. Major anions $\left(\mathrm{F}^{-}, \mathrm{Cl}^{-}, \mathrm{Br}^{-}, \mathrm{SO}_{4}^{2-}\right.$ and $\left.\mathrm{NO}_{3}^{-}\right)$and cations $\left(\mathrm{Ca}^{2+}, \mathrm{Mg}^{2+}, \mathrm{Na}^{+}\right.$and $\left.\mathrm{K}^{+}\right)$were analyzed by ionchromatography (IC; Thermo Scientific Dionex ICS-900) on filtered and filtered-acidified $(\mathrm{HCl})$ samples, respectively. An unfiltered 
Table 1

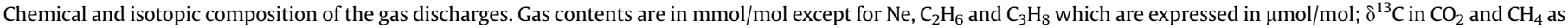
$\%$ V-PDB; $\delta$ D in $\mathrm{CH}_{4}$ as \%o V-SMOW; $\delta^{15} \mathrm{~N}$ as \%o NBS air; $\delta^{34} \mathrm{~S}$ as \%o V-CDT. Data from samples 190-216 are taken from Cinti et al. (2014).

\begin{tabular}{|c|c|c|c|c|c|c|c|c|c|c|c|c|c|}
\hline ID & \multicolumn{2}{|l|}{ Site } & $\mathrm{CO}_{2}$ & $\mathrm{H}_{2} \mathrm{~S}$ & $\mathrm{~N}_{2}$ & $\mathrm{CH}_{4}$ & $\mathrm{Ar}$ & $\mathrm{O}_{2}$ & $\mathrm{H}_{2}$ & $\mathrm{He}$ & $\mathrm{Ne}$ & $\mathrm{C}_{2} \mathrm{H}_{6}$ & $\mathrm{C}_{3} \mathrm{H}_{8}$ \\
\hline 10 & \multicolumn{2}{|c|}{ trevignano 1} & 966 & 1.10 & 31 & 0.37 & 0.62 & 0.91 & 0.0150 & 0.0006 & 0.00123 & 3.5 & 0.61 \\
\hline 50 & \multicolumn{2}{|c|}{ monte caio } & 968 & 0.33 & 29 & 0.16 & 0.55 & 2.4 & 0.0080 & 0.0009 & 0.00099 & 7.1 & 0.80 \\
\hline 77 & \multicolumn{2}{|c|}{ fosso s. antonino } & 961 & 2.10 & 33 & 1.9 & 0.75 & 0.62 & 0.0190 & 0.0013 & 0.00080 & 66 & 9.0 \\
\hline 121 & \multicolumn{2}{|c|}{ castel campanile } & 960 & & 36 & 2.7 & 0.71 & 0.21 & 0.0160 & 0.0015 & 0.00025 & 78 & 9.0 \\
\hline 135 & \multicolumn{2}{|c|}{ acqua forte ponzano } & 966 & 0.29 & 32 & 0.85 & 0.76 & 0.39 & 0.0041 & 0.0045 & 0.00067 & 7.8 & 0.85 \\
\hline 190 & \multicolumn{2}{|c|}{ mola bassano } & 993 & 0.02 & 6.0 & 0.35 & 0.056 & 0.10 & 0.0392 & 0.0003 & 0.00003 & 2.1 & 0.10 \\
\hline 191 & \multicolumn{2}{|c|}{ pian del vescovo } & 994 & 0.04 & 5.1 & 0.31 & 0.071 & 0.09 & 0.0532 & 0.0004 & 0.00004 & 3.0 & 0.11 \\
\hline 201 & \multicolumn{2}{|c|}{ terme dei gracchi 2} & 992 & 0.08 & 7.9 & 0.06 & 0.133 & 0.10 & 0.0085 & 0.0007 & 0.00005 & 0.55 & 0.02 \\
\hline 216 & \multicolumn{2}{|c|}{ solforate nepi } & 994 & 0.43 & 5.4 & 0.07 & 0.049 & 0.06 & 0.0160 & 0.0021 & 0.00003 & 0.22 & 0.01 \\
\hline ID & $\mathrm{R} / \mathrm{R}_{\mathrm{a}}$ & ${ }^{4} \mathrm{He} /{ }^{20} \mathrm{Ne}$ & \multicolumn{2}{|c|}{${ }^{40} \mathrm{Ar} /{ }^{36} \mathrm{Ar}$} & $\delta^{13} \mathrm{C}-\mathrm{CO}_{2}$ & \multicolumn{2}{|c|}{$\delta^{13} \mathrm{C}-\mathrm{CH}_{4}$} & $\delta \mathrm{D}-\mathrm{CH}_{4}$ & $\delta^{15} \mathrm{~N}-\mathrm{N}_{2}$ & $\delta^{34} \mathrm{~S}-\mathrm{H}_{2} \mathrm{~S}$ & \multicolumn{2}{|c|}{$\begin{array}{l}{ }^{3} \mathrm{He} \\
\left(\times 10^{-10}\right)\end{array}$} & $\begin{array}{l}\mathrm{CO}_{2} /^{3} \mathrm{He} \\
\left(\mathrm{x} 10^{12}\right)\end{array}$ \\
\hline 10 & 0.61 & 0.49 & \multicolumn{2}{|c|}{290.9} & 0.26 & \multicolumn{2}{|c|}{-29.2} & -155 & & 9.5 & \multicolumn{2}{|c|}{5.1} & 19 \\
\hline 50 & 0.74 & 0.94 & \multicolumn{2}{|c|}{301.4} & -4.73 & \multicolumn{2}{|c|}{-30.6} & -154 & & 9.7 & \multicolumn{2}{|c|}{9.6} & 10 \\
\hline 77 & 1.04 & 16.1 & \multicolumn{2}{|c|}{297.5} & 1.02 & \multicolumn{2}{|c|}{-33.4} & -166 & & 10.3 & \multicolumn{2}{|c|}{19} & 5.1 \\
\hline 121 & 0.07 & 6.11 & \multicolumn{2}{|c|}{293.4} & -1.69 & \multicolumn{2}{|c|}{-25.2} & -160 & 1.6 & & \multicolumn{2}{|c|}{1.6} & 60 \\
\hline 135 & 0.88 & 6.65 & \multicolumn{2}{|c|}{304.9} & -0.47 & & & -165 & & 10.6 & 55 & & 1.8 \\
\hline 190 & & 0.79 & & & -1.06 & & & -147 & & 9.3 & & & \\
\hline 191 & 0.71 & 2.23 & & & -0.04 & & & -140 & & 11.3 & 4. & & 25 \\
\hline 201 & 0.69 & 1.62 & & & -1.93 & & & -168 & 0.91 & 9.6 & 6. & & 15 \\
\hline 216 & 0.55 & 1.13 & & & -1.22 & & & -149 & 3.7 & 9.8 & 16 & & 6.1 \\
\hline
\end{tabular}

diluted $(1: 10)$ sample was collected for the determination of $\mathrm{SiO}_{2}$ by molecular spectrophotometry (MS). The analytical errors for IC and MS were $<5 \%$. An unfiltered sample was collected for the determination of $\mathrm{NH}_{4}$ by Ion-Selective Electrode method (ISE). The analytical error for ISE was $<10 \%$. Minor and trace elements $(\mathrm{B}, \mathrm{Li}$, $\mathrm{Fe}, \mathrm{Mn}, \mathrm{Al}, \mathrm{Sr}$ ) were determined on the filtered-acidified (with $\mathrm{HNO}_{3}$ ) samples by inductively coupled plasma mass spectrometry (ICP-MS; Agilent 7500ce). The analytical error for ICP-MS was $<10 \%$.

The ${ }^{18} \mathrm{O} /{ }^{16} \mathrm{O}$ and ${ }^{2} \mathrm{H} /{ }^{1} \mathrm{H}$ ratios of water (expressed as $\delta^{18} \mathrm{O}-\mathrm{H}_{2} \mathrm{O}$ and $\delta \mathrm{D}-\mathrm{H}_{2} \mathrm{O} \% \mathrm{~V}$-SMOW) were determined by isotope ratio mass spectrometry (IRMS). Oxygen isotopes measurements were carried out by using a Gas Bench peripheral coupled with a Thermo Delta V mass spectrometer. A TC-EA peripheral interfaced by means of a ConFloIV with Thermo Delta XP mass spectrometer was used for hydrogen isotopes. The analytical error for IRMS was $\pm 0.1 \%$ of $\delta^{18} \mathrm{O}$ and better than $\pm 1 \%$ for $\delta \mathrm{D}$. The ${ }^{13} \mathrm{C} /{ }^{12} \mathrm{C}$ isotopic ratios of Total Dissolved Inorganic Carbon (TDIC), expressed as $\delta^{13} \mathrm{C}$-TDIC \% $\mathrm{V}$ PDB, were analyzed by mass spectrometry (Finnigan Delta plus XP) following the procedure described by Salata et al. (2000). The analytical error for MS was $\pm 0.1 \%$.

\subsection{Dissolved and free gas sampling and analysis}

Water samples for the determination of dissolved gases were collected in $125 \mathrm{~mL}$ glass flasks equipped with a rubber septum. Dissolved gas chemistry $\left(\mathrm{H}_{2}, \mathrm{He}, \mathrm{O}_{2}, \mathrm{~N}_{2}, \mathrm{CH}_{4}, \mathrm{CO}_{2}, \mathrm{Ne}\right)$ was determined in the free-gas phase, formed in the headspace of the sampling flasks by injecting Ar through the rubber septum, by gas chromatography (GC) using a Varian CP-4900 Micro gas chromatograph equipped with two TCD detectors and $\mathrm{Ar}$ as carrier gas (Capasso and Inguaggiato, 1998). The dissolved gas concentrations (expressed in bar) were calculated from the composition of the headspace gas on the basis of the solubility coefficients of each gas compound (Whitfield, 1978). Analytical error for GC was $<5 \%$.

Free gases were collected from bubbling pools by using a plastic funnel positioned above the gas emergence and connected to glass thorion-tapped flasks through a silicon tube. Three gas aliquots were collected, as follows: 1 ) a pre-evacuated $150 \mathrm{~mL}$ glass flask for the determination of ${ }^{13} \mathrm{C} /{ }^{12} \mathrm{C},{ }^{40} \mathrm{Ar} /{ }^{36} \mathrm{Ar},{ }^{3} \mathrm{He} /{ }^{4} \mathrm{He}$ and ${ }^{4} \mathrm{He} /{ }^{20} \mathrm{Ne}$ isotopic ratios; 2) a pre-evacuated $150 \mathrm{~mL}$ glass flask filled with
$50 \mathrm{~mL}$ of a $4 \mathrm{~N} \mathrm{NaOH}$ solution for the determination of carbon and hydrogen and nitrogen isotopes in $\mathrm{CH}_{4}$ and $\mathrm{N}_{2}$, respectively; 3) a pre-evacuated $60 \mathrm{~mL}$ glass flask filled with $20 \mathrm{~mL}$ of a $5 \mathrm{~N} \mathrm{NaOH}$ and $0.15 \mathrm{M} \mathrm{Cd}(\mathrm{OH})_{2}$ suspension for the determination of the chemical composition and ${ }^{34} \mathrm{~S} /{ }^{32} \mathrm{~S}$ isotopic ratio in $\mathrm{H}_{2} \mathrm{~S}$ (Giggenbach and Goguel, 1989; Montegrossi et al., 2001; Vaselli et al., 2006). Lowsolubility inorganic gases and $\mathrm{CH}_{4}$ were analyzed by GC using a Shimadzu 15A gas chromatograph, equipped with a $10 \mathrm{~m}$ long $5 \mathrm{~A}$ molecular sieve column and a thermal conductivity detector (TCD), and a Thermo Focus gas chromatograph equipped with a $30 \mathrm{~m}$ long capillary molecular sieve column and a TCD. Light hydrocarbons were determined with a Shimadzu $14 \mathrm{~A}$ gas chromatograph equipped with a $10 \mathrm{~m}$ long stainless steel column $(\phi=2 \mathrm{~mm})$ packed with Chromosorb PAW 80/100 mesh coated with 23\% SP 1700 and equipped with a FID detector. $\mathrm{CdS}$ in the solid precipitate of aliquot (3), formed by the reaction of $\mathrm{Cd}$ and $\mathrm{H}_{2} \mathrm{~S}$, was separated from the liquid phase by centrifugation at $4000 \mathrm{rpm}$ for $30 \mathrm{~min}$, oxidized to $\mathrm{SO}_{4}^{2-}$ by $\mathrm{H}_{2} \mathrm{O}_{2}$, and then analyzed by IC (Methrom 761). Carbon dioxide was analyzed as $\mathrm{CO}_{3}^{2-}$ in the alkaline solution by acidimetric titration with $0.1 \mathrm{~N} \mathrm{HCl}$. The analytical error for the gas chemical analysis was $<10 \%$.

The ${ }^{13} \mathrm{C} /{ }^{12} \mathrm{C}$ isotopic ratios in $\mathrm{CO}_{2}$ (expressed as $\delta^{13} \mathrm{C} \%$ V-PDB) were determined by MS using a Finningan Delta $\mathrm{S}$ mass spectrometer, after a two-step extraction and purification procedures of the gas mixtures by using liquid $\mathrm{N}_{2}$ and a solid-liquid mixture of liquid $\mathrm{N}_{2}$ and trichloroethylene. Internal (Carrara and San Vincenzo marbles) and international (NBS18 and NBS19) standards were used to estimate external precision. The analytical error and the reproducibility were $\pm 0.05 \%$ and $\pm 0.1 \%$, respectively.

The ${ }^{13} \mathrm{C} /{ }^{12} \mathrm{C}$ and ${ }^{2} \mathrm{H} /{ }^{1} \mathrm{H}$ isotopic ratios in $\mathrm{CH}_{4}$ (expressed as $\delta{ }^{13} \mathrm{C}$ $\%$ V-PDB and $\delta \mathrm{D} \%$ V-SMOW) were analyzed by mass spectrometry (Varian MAT 250) according to the procedure described in Schoell (1980). The analytical error was $\pm 0.15 \%$ for $\delta^{13} \mathrm{C}$ and $\pm 1 \%$ for $\delta \mathrm{D}$. The ${ }^{34} \mathrm{~S} /{ }^{32} \mathrm{~S}$ isotopic ratios in $\mathrm{H}_{2} \mathrm{~S}$ (expressed as $\delta^{34} \mathrm{~S} \% \mathrm{~V}$-CDT) were determined after the precipitation of $\mathrm{SO}_{4}^{2-}$, produced by the oxidation of $\mathrm{CdS}$ precipitated in the aliquot (3), as $\mathrm{BaSO}_{4}$ by adding a $\mathrm{BaCl}_{2}$ solution $(10 \% \mathrm{w} / \mathrm{v})$. Sulfur isotopes in $\mathrm{H}_{2} \mathrm{~S}$ were analyzed by using an EA-IRMS system consisting of a 20-20 isotope ratio mass spectrometer (Europa Scientific, Crewe, UK), equipped with an elemental analyzer (Sercon Ltd., Crewe, UK). The analytical error was $<0.3 \%$. Nitrogen isotopes in $\mathrm{N}_{2}$ (expressed as $\delta^{15} \mathrm{~N} \%$ NBS air) 
were determined with an Agilent 6890N gas-chromatograph coupled to a Finnigan Delta plus XP mass spectrometer. Helium isotopic ratios (expressed as $R / R_{a}$, where $\mathrm{R}$ is the ${ }^{3} \mathrm{He} /{ }^{4} \mathrm{He}$ measured ratio and $\mathrm{R}_{\mathrm{a}}$ is the ${ }^{3} \mathrm{He} /{ }^{4} \mathrm{He}$ ratio in the air: $1.39 \times 10^{-6}$; Mamyrin and Tolstikhin, 1984), as well as the ${ }^{4} \mathrm{He} /{ }^{20} \mathrm{Ne}$ and ${ }^{40} \mathrm{Ar} /{ }^{36} \mathrm{Ar}$ ratios, were analyzed by a GVI Helix SFT mass spectrometer after gas samples purification in the high-vacuum inlet line of the instrument (Rizzo et al., 2015). The analytical error in the determination of elemental He and Ne contents was $<5 \%$.

\section{Results}

\subsection{Chemical and isotopic composition of waters}

Cold waters from both the volcanic and sedimentary domains (Fig. 1) are characterized by low Total Dissolved Solids (TDS) values ( $<1000 \mathrm{mg} / \mathrm{L}$ ), slightly acidic-to-alkaline $\mathrm{pH}$ values (from 6.3 to 8.0 ) and $\mathrm{Ca}-\mathrm{HCO}_{3}$ to $\mathrm{Ca}(\mathrm{Na})-\mathrm{HCO}_{3}$ chemical composition (Fig. $2 \mathrm{a}$ and $\mathrm{b}$ ). Exceptions are a significant number of cold waters, locally known as acque acetose (samples 15, 24, 45, 46, 48, 50, 51, 52, 57, 64, 68, 70, $75,77,80,84,91,97,101,122,127,128,129,135,136,146,147,154$, $179,199,200,201,207,213,214)$, which are characterized by relatively high TDS (up to $4014 \mathrm{mg} / \mathrm{L}$ ) and lower pH values (from 5.2 to 6.7). Relatively few cold waters show a Ca-SO ${ }_{4}$ composition (samples 54, 65, 67, 93, 121, 191 and 206) and have variable TDS (from 239 to $3827 \mathrm{mg} / \mathrm{L}$ ) and $\mathrm{pH}$ (from 3.1 to 6.7) values. The concentrations of minor and trace elements are marked by a large variability, as follows: Li from 0.005 to $0.80 \mathrm{mg} / \mathrm{L}, \mathrm{B}$ from 0.02 to $6.8 \mathrm{mg} /$ $\mathrm{L}, \mathrm{Al}$ from 0.005 to $78 \mathrm{mg} / \mathrm{L}, \mathrm{Mn}$ from 0.005 to $5.5 \mathrm{mg} / \mathrm{L}$, Fe from 0.005 to $112 \mathrm{mg} / \mathrm{L}, \mathrm{Sr}$ from 0.08 to $6.8 \mathrm{mg} / \mathrm{L}$.

Thermal waters (from 22.5 to $61.5^{\circ} \mathrm{C}$ ) have relatively high TDS values (from 1179 to $4035 \mathrm{mg} / \mathrm{L}$ ), with the exception of sample 190 (493 mg/L), and slightly acidic pH (from 5.2 to 6.6). They show a Ca$\mathrm{HCO}_{3}\left(\mathrm{SO}_{4}\right)$ to $\mathrm{Na}(\mathrm{Ca})-\mathrm{HCO}_{3}(\mathrm{Cl})$ composition (Fig. 2a and b), and concentrations of $\mathrm{Li}, \mathrm{B}, \mathrm{Fe}, \mathrm{Al}, \mathrm{Mn}$ and $\mathrm{Sr}$, are marked by a large variability $(49-1424,211$ to $8161,0.71$ to $7156,3.3$ to 176 , $0.32-827 \mu \mathrm{g} / \mathrm{L}$ and $0.23-9.2 \mathrm{mg} / \mathrm{L}$, respectively).

The $\delta^{18} \mathrm{O}-\mathrm{H}_{2} \mathrm{O}$ and $\delta^{2} \mathrm{H}-\mathrm{H}_{2} \mathrm{O}$ values range from -7.1 to $-4.7 \%$ and from -44 to $-30 \%$ V-SMOW, respectively (Table $1 \mathrm{~S}$ ), with no significant difference between cold and thermal waters, with the exception of sample 121, associated with bubbling gases, that can be distinguished by a strongly negative $\delta^{18} \mathrm{O}-\mathrm{H}_{2} \mathrm{O}$ and $\delta^{2} \mathrm{H}-\mathrm{H}_{2} \mathrm{O}$ values ( -14.9 and $-27 \%$ V-SMOW, respectively).

The $\delta^{13} \mathrm{C}$-TDIC values range from -21.2 to $+5.39 \%$ V-PDB
(Table 2S).

\subsection{Chemical and isotopic composition of dissolved gases}

The dissolved gases mainly consist of atmospheric compounds $\left(\mathrm{N}_{2}\right.$ and $\left.\mathrm{O}_{2}\right)$, whose partial pressures are up to 0.98 and 0.20 bar, respectively. The $p \mathrm{CO}_{2}$ values are low $(<0.038$ bar $)$ in the cold bicarbonate-type waters (Table 2S) and significantly higher in acque acetose (up to 0.35 bar), in $\mathrm{SO}_{4}$-rich cold waters (up to 0.36 bar) and thermal waters (up to 0.27 bar). The partial pressures of the other gas compounds show relatively large variations in terms of concentration $\left(p \mathrm{CH}_{4}\right.$ from $6.8 \times 10^{-7}$ to 0.291 bar, $p \mathrm{He}$ from $1 \times 10^{-7}$ to $1.5 \times 10^{-4}$ bar, and $\mathrm{pH}_{2}$ from $1.0 \times 10^{-7}$ to $1.4 \times 10^{-5}$ bar), with no significant differences among those gases associated with waters having different outlet temperatures (Table 2S).

The $\delta^{13} \mathrm{C}$ values of dissolved $\mathrm{CO}_{2}$ are calculated from the $\delta^{13} \mathrm{C}$ TDIC values using the empirical equation of Zhang et al. (1995), as follows:

$$
\begin{aligned}
\delta^{13} \mathrm{C}_{\mathrm{CO}_{2}(\mathrm{~g})=} & \delta^{13} \mathrm{C}_{\mathrm{TDIC}}-\frac{\mathrm{H}_{2} \mathrm{CO}_{3}}{\mathrm{TDIC}} \varepsilon_{\left(\mathrm{H}_{2} \mathrm{CO}_{3}-\mathrm{CO}_{2}\right)}-\frac{\mathrm{HCO}_{3}^{-}}{\mathrm{TDIC}} \varepsilon_{\left(\mathrm{HCO}_{3}^{-}-\mathrm{CO}_{2}\right)} \\
& -\frac{\mathrm{CO}_{3}^{2-}}{\mathrm{TDIC}} \varepsilon_{\left(\mathrm{CO}_{3}^{2-}-\mathrm{CO}_{2}\right)}
\end{aligned}
$$

where the equilibrium molar ratios of aqueous carbon species at sampling temperature and $\mathrm{pH}$, used in Eq. (1), are computed with the PHREEQC code (Parkhurst and Appelo, 2013), whereas the value given by Deuser and Degens (1967) and Mook et al. (1974) is used for the isotope fractionation factor $(\varepsilon)$ between dissolved and gaseous $\mathrm{CO}_{2}$. The calculated $\delta^{13} \mathrm{C}_{-} \mathrm{CO}_{2}$ values range from -27.3 and $+2.94 \%$ V-PDB (Table $2 S$ ).

\subsection{Chemical and isotopic composition of free gases}

The chemical composition of gases discharged from bubbling pools (Table 1) is dominated by $\mathrm{CO}_{2}$ (from 960 to $994 \mathrm{mmoL} / \mathrm{mol}$ ), whilst $\mathrm{N}_{2}$ and $\mathrm{CH}_{4}$ concentrations range from 5.1 to 36 and from 0.06 to $2.7 \mathrm{mmoL} / \mathrm{mol}$, respectively. Oxygen and $\mathrm{Ar}$ concentrations vary from 0.06 to 2.4 and $0.05-0.76 \mathrm{mmoL} / \mathrm{mol}$, respectively. Hydrogen sulfide is detected in all the gas samples (from 0.02 to $2.1 \mathrm{mmoL} / \mathrm{mol}$ ), with the only exception of sample 121 $(<0.01 \mathrm{mmoL} / \mathrm{mol})$. Hydrogen, He and Ne have concentrations up to

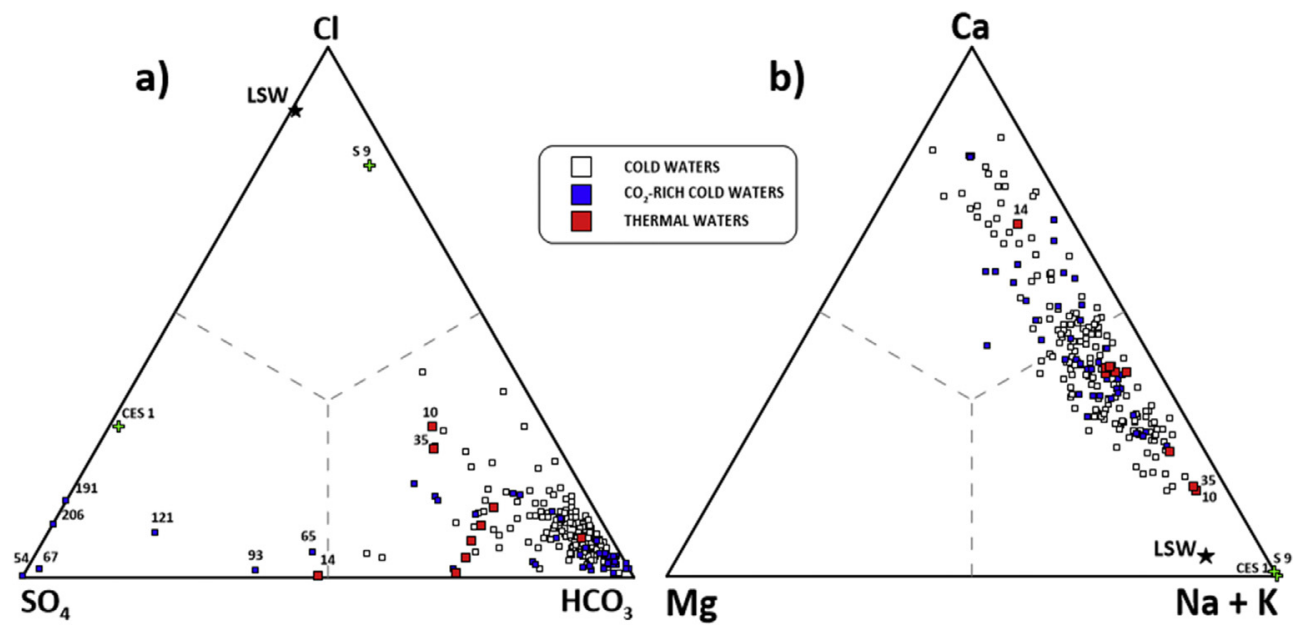

Fig. 2. a) $\mathrm{HCO}_{3}-\mathrm{Cl}-\mathrm{SO}_{4}$ and b) $(\mathrm{Na}+\mathrm{K})-\mathrm{Ca}-\mathrm{Mg}$ ternary diagrams for waters from the study area. LSW = local seawater; CES 1 , S9 = geothermal wells. 
$0.05,0.0045$ and $0.0012 \mathrm{mmoL} / \mathrm{mol}$, respectively, while the sum of the $\mathrm{C}_{2}-\mathrm{C}_{4}$ alkanes range from $0.0002 \mathrm{mmoL} / \mathrm{mol}$ (sample 210) to $0.10 \mathrm{mmoL} / \mathrm{mol}$ (sample 121). Carbon monoxide is below the analytical detection limit $(0.01 \mathrm{mmoL} / \mathrm{mol})$.

The ${ }^{13} \mathrm{C} /{ }^{12} \mathrm{C}$ isotopic ratios in $\mathrm{CO}_{2}$ and $\mathrm{CH}_{4}$ are from -4.7 to $+1.0 \%$ and from -33.4 to $-24.9 \%$ V-PDB, respectively, while the $\delta \mathrm{D}-\mathrm{CH}_{4}$ values range from -168 to $-140 \%$ V-SMOW. The $\mathrm{R} / \mathrm{R}_{\mathrm{a}}$ values, corrected for air contamination by using the ${ }^{4} \mathrm{He} /{ }^{20} \mathrm{Ne}$ ratios (Poreda and Craig, 1989), vary between 0.07 and 1.04 . The ${ }^{40} \mathrm{Ar} /{ }^{36} \mathrm{Ar}$ ratios of most gases are consistent with that of the atmosphe (295.5; Ozima and Podosek, 2002), whereas samples 50 and 135 show a slight ${ }^{40} \mathrm{Ar}$-excess (301.4 and 304.9, respectively). The $\delta^{34} \mathrm{~S}$ $\mathrm{H}_{2} \mathrm{~S}$ values range from +9.3 to $+11.3 \%$ V-CDT, whereas the $\delta^{15} \mathrm{~N}-\mathrm{N}_{2}$ values vary from +0.91 to $+3.7 \%$ NBS air.

\section{Discussion}

\subsection{Processes governing the chemical and isotopic composition of} waters

As shown in the $\delta \mathrm{D}$ vs. $\delta^{18} \mathrm{O}$ diagram (Fig. 3a), most cold and thermal waters plot in between the Global Meteoric Water Line (GMWL; Craig, 1961) and the Mediterranean Meteoric Water Line (MMWL; Gat and Carmi, 1970). The only exception is represented by the sample 121 , whose strongly negative ${ }^{18} \mathrm{O}$ value is likely resulting by ${ }^{18} \mathrm{O}-{ }^{16} \mathrm{O}$ isotopic exchange between $\mathrm{H}_{2} \mathrm{O}$ and $\mathrm{CO}_{2}$ (e.g., Cartwright et al., 2002). The ${ }^{18} \mathrm{O}$ vs. emergence elevation diagram for the cold springs (Fig. 3b) shows a mean isotopic vertical gradient of $-0.24 \% / 100 \mathrm{~m}$, which is similar to those previously calculated for central Italy (Zuppi et al., 1974; Barbieri et al., 2005). This allows to estimate the average altitude of the recharge areas at approximately $300-400 \mathrm{~m}$ a.s.l., whereas the generally low vertical drop ( 100-200 $\mathrm{m}$ ) between infiltrating and emergence altitudes suggests that the cold springs pertain to relatively short and shallow hydrological circuits through the volcanic and sedimentary units. Accordingly, the main chemical features of the low-TDS bicarbonate-type cold waters are typical of immature fluids. However, weak water-rock interaction processes occurring in the lowtemperature shallow volcanic aquifer favor the mobilization of ions such as $\mathrm{K}^{+}$(Fig. 1Sa) and $\mathrm{F}^{-}$(Fig. 1Sb), whose enrichments in solution are due to their relatively high abundance in the rocks of the Tuscan and Roman volcanic sequences with respect to those occurring in the sedimentary formations (Gambardella et al., 2005; De Rita et al., 2011).

The main chemical features of the acque acetose, i.e. high $\mathrm{HCO}_{3}^{-}$ concentrations and slightly acidic $\mathrm{pH}$ (Fig. 4), likely derive from the interaction of the shallow aquifers with the $\mathrm{CO}_{2}$-rich gas phase released from the deep pressurized regional fluid reservoir (Minissale, 2004). Strongly acidic ( $\mathrm{pH}$ down to 3.1), $\mathrm{SO}_{4}$-dominated waters (samples 54, 67, 191, 206; Fig. 4) are produced by nearsurface oxidation of $\mathrm{H}_{2} \mathrm{~S}$, which is present at significant concentrations in the associated $\mathrm{CO}_{2}$-rich gas phase, to $\mathrm{H}_{2} \mathrm{SO}_{4}$ as described by the following chemical reaction (Rye et al., 1992):

$\mathrm{H}_{2} \mathrm{~S}+2 \mathrm{O}_{2} \rightarrow \mathrm{H}_{2} \mathrm{SO}_{4} \rightarrow 2 \mathrm{H}^{+}+\mathrm{SO}_{4}^{2-}$

In these waters, $\mathrm{O}_{2}$ consumption causes reducing conditions and the low pH values, caused by reaction (2), explain the high concentrations of $\mathrm{Al}, \mathrm{Mn}$ and Fe (Table 1S).

The thermal water discharges are related to the well-recognized regional hydrothermal aquifer hosted in the Mesozoic carbonates at the top of the Triassic anhydrite layers and recharged by meteoric waters from the eastern Apennine range (Chiodini et al., 2000; Minissale, 2004; Minissale and Vaselli, 2011; Cinti et al., 2014). Their main chemical features are indeed dominated by relatively high concentrations of $\mathrm{Ca}^{2+}, \mathrm{Mg}^{2+}, \mathrm{SO}_{4}^{2-}$ and $\mathrm{HCO}_{3}^{-}$. However, their $\left[\mathrm{HCO}_{3}^{-}+\mathrm{SO}_{4}^{2-}\right] /\left[\mathrm{Ca}^{2+}+\mathrm{Mg}^{2+}\right]$ ratios are $>1$ (Fig. 5a), i.e. higher than the stoichiometric ratio expected when carbonate and anhydrite dissolution is assumed as the unique source of these ionic species (i.e. $\left[\mathrm{HCO}_{3}^{-}+\mathrm{SO}_{4}^{2-}\right] /\left[\mathrm{Ca}^{2+}+\mathrm{Mg}^{2+}\right]=1$ ). This suggests that $\mathrm{HCO}_{3}^{-}$ and $\mathrm{SO}_{4}^{2-}$ derive, at least partially, from the interaction of waters with the $\mathrm{CO}_{2}$ - and $\mathrm{H}_{2} \mathrm{~S}$-rich gases. Few thermal waters (samples 10 , 35,166 ), i.e. those with the highest TDS values (from 3450 to $4060 \mathrm{mg} / \mathrm{L}$ ), show relatively high $\mathrm{Na}^{+}$and $\mathrm{Cl}^{-}$concentrations (Table $1 \mathrm{~S}$ ), possibly caused by mixing between the deep thermal fluids uprising from the carbonate-evaporitic aquifer and highly saline waters locally trapped in the Neogene marine sediments below the volcanic sequences (Calamai et al., 1976; Duchi et al., 1992; Dall'Aglio et al., 1994; Minissale et al., 1997b). The possible involvement of the deep and hot $\mathrm{Na}-\mathrm{Cl}$ brine intercepted from the geothermal wells at Cesano (Calamai et al., 1976) in the chemical features of the $\mathrm{Na}-\mathrm{Cl}$-rich thermal waters cannot completely be discarded, since the $\mathrm{Na}^{+} / \mathrm{Cl}^{-}$molar ratios of these waters are up to 2, i.e. higher than the stoichiometric ratio and approaching that shown by the geothermal fluid (Fig. 5b). However, these relatively high $\mathrm{Na}^{+} / \mathrm{Cl}^{-}$molar ratios may also be related to $\mathrm{Na}^{+}$contribution from alteration processes of silicate minerals (e.g. clay minerals, zeolites or feldspatoids), which are favored by both high temperature and $\mathrm{CO}_{2}$.

As far as the minor elements are concerned, relatively high $\mathrm{Sr}$ concentrations are found in most thermal and $\mathrm{SO}_{4}$-rich cold waters (Fig. 2Sa), this element being a common $\mathrm{Ca}^{2+}$ substituent in carbonate and gypsum/anhydrite minerals, which are abundantly present in the Mesozoic and Triassic reservoir rocks (Barbieri et al., 1979; Minissale et al., 1997b). Lithium and B concentrations, two elements that are typically enriched in geothermal waters, are generally low in both the cold and thermal waters. Exceptions are the above-mentioned $\mathrm{Na}-\mathrm{Cl}$-rich thermal waters (samples 10, 35 and 166; Fig. 2Sb,c), whose high concentrations of these elements would support the hypothesis of mixing with saline fluids trapped in the Neogene marine sediments rather than that of fluid contribution from the deep $\mathrm{Na}-\mathrm{Cl}$ brine. This is confirmed by the very low $\mathrm{NH}_{4}^{+}$concentrations, since this compound typically occurs in the main geothermal reservoirs of Tuscany and Latium (i.e. Larderello, Torre Alfina, Latera, Cesano), deriving from the dissolution of $\mathrm{NH}_{3}$ rich vapors (Calamai et al., 1976; Duchi et al., 1992; Minissale et al., 1997b).

The degree of maturity of waters from cold and thermal springs interacting with a typical authigenic mineral assemblage (including Na- and K-feldspars, K-micas, chlorite and silica) is commonly investigated on the basis of their $\mathrm{Na}^{+}, \mathrm{K}^{+}$, and $\mathrm{Mg}^{2+}$ concentrations. When water-rock reactions attain a chemical equilibrium, reliable estimations of the fluid reservoir temperatures can be carried out, as described by the following equations (Giggenbach, 1988):

$T\left({ }^{\circ} \mathrm{C}\right)=1,390 /\left(1.75+\log \left[\mathrm{Na}^{+} / \mathrm{K}^{+}\right]\right)-273.15$

and

$T\left({ }^{\circ} \mathrm{C}\right)=4,410 /\left(14.0-\log \left[\left(\mathrm{K}^{+}\right)^{2} / \mathrm{Mg}^{2+}\right]\right)-273.15$

As shown by the $\mathrm{Na}^{+} / 400-\mathrm{K}^{+} / 10-\sqrt{ } \mathrm{Mg}^{2+}$ ternary diagram (Fig. 3S), the eastern SVD waters are strongly immature, thus the K$\mathrm{Mg}$ and Na-K geothermometers cannot usefully be applied. This is confirmed by the low equilibrium temperatures computed by the silica (chalcedony) geothemometer (Arnorsson et al., 1983) that, according to the concentrations measured in the thermal waters, ranges from 78 to $125{ }^{\circ} \mathrm{C}$, i.e. significantly lower than those measured in the geothermal wells in this area. The unrealistic 

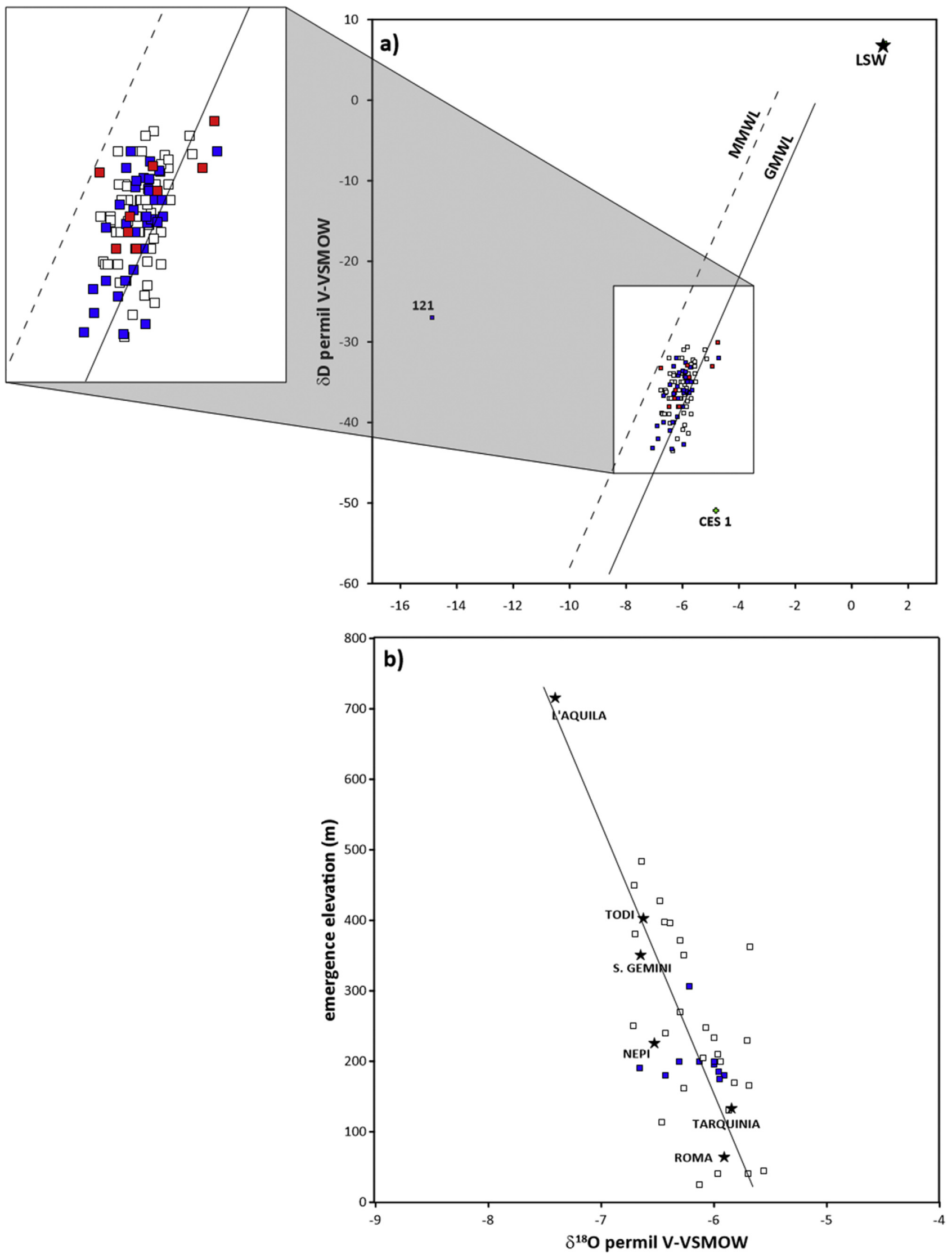

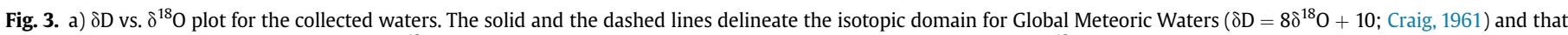

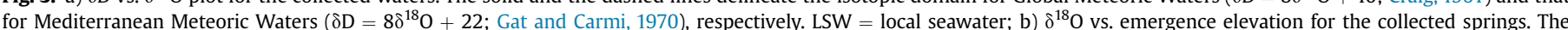

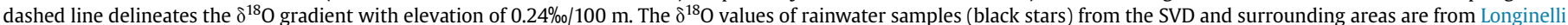
and Selmo (2003). Symbols as in Fig. 2. 


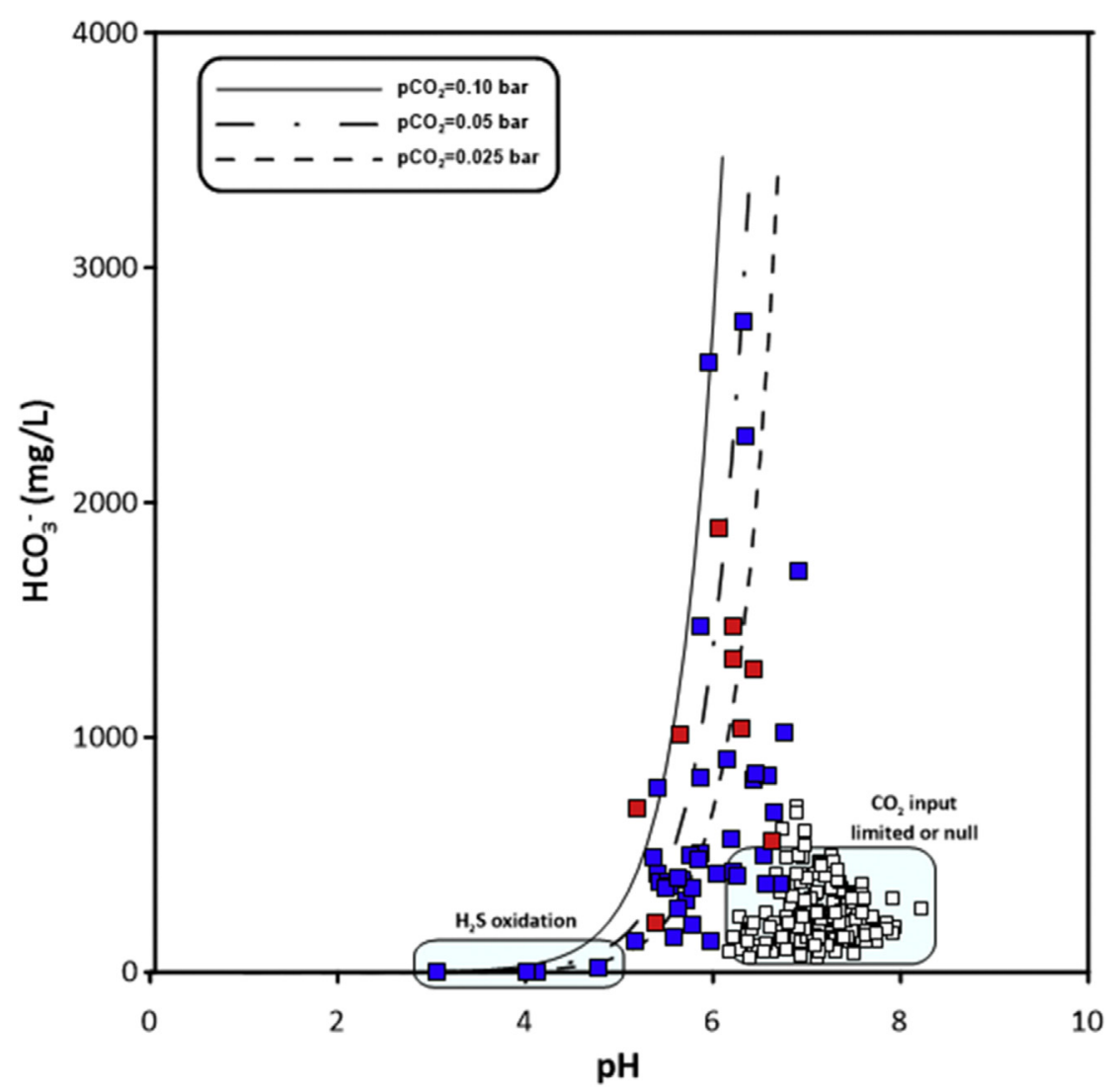

Fig. 4. $\mathrm{HCO}_{3}$ vs. pH binary diagram for the collected waters. $\mathrm{CO}_{2}$ saturation curves at $\mathrm{pCO}_{2}=0.10,0.05$ and 0.025 bar are also reported. Symbols as in Fig. 2 .

estimations of fluid temperatures provided by solute geothermometers suggest that, even along the main tectonic lineaments where the fast rising of deep fluids is favored, the chemistry of the thermal fluids is affected by mixing with shallow waters.

\subsection{Origin of gas compounds}

\subsubsection{Carbon species}

It is widely accepted (e.g., Minissale et al., 1997b; Chiodini et al., 1999; Minissale, 2004) that the origin of $\mathrm{CO}_{2}$ in central Italy is related to a twofold source, i.e. mantle degassing $\left(\delta^{13} \mathrm{C}_{-} \mathrm{CO}_{2}\right.$ from -7.0 to $-3.0 \%$ V-PDB; Javoy et al., 1982; Rollinson, 1993) and thermo-metamorphic reactions on carbonates and/or the underlying metamorphic Palaeozoic basement $\left(\delta^{13} \mathrm{C}_{-} \mathrm{CO}_{2}\right.$ from -2.0 to $+2.0 \%$ V-PDB; Craig, 1963). The $\delta^{13} \mathrm{C}_{-} \mathrm{CO}_{2}$ values of the free gases in the eastern SVD, which are in the typical range of gas manifestations from the Roman Magmatic Province (Chiodini et al., 2000, 2007; Minissale, 2004; Cinti et al., 2011, 2014), are consistent with this hypothesis. The relatively high $\mathrm{CO}_{2} /{ }^{3} \mathrm{He}$ values (up to $6.0 \times 10^{12}$; Fig. 6a), i.e. exceeding more than three orders of magnitude that of MORB mantle $\left(1.4 \times 10^{9}\right.$; Marty and Jambon, 1987), support a dominant $\mathrm{CO}_{2}$ crustal source. According to the correlation between the calculated $\delta^{13} \mathrm{C}$ values of dissolved $\mathrm{CO}_{2}$ and the $p \mathrm{CO}_{2}$ values (Fig. $6 \mathrm{~b}$ ), $\mathrm{CO}_{2}$ in the $\mathrm{CO}_{2}$-poor cold waters likely originates from soil respiration (e.g., Cerling et al., 1991; Cartwright et al., 2002), whereas the isotopically heavy $\mathrm{CO}_{2}$ from the $\mathrm{CO}_{2}$-rich cold and thermal waters has the same deep crustal/mantle source feeding the bubbling gases. Dissolved $\mathrm{CO}_{2}$ in waters showing intermediate $\mathrm{pCO}_{2}$ values is likely due to mixing processes between these two end-members.

Methane is defined as microbial (or biogenic), when produced by (i) metabolic processes of microbial communities at relatively low temperatures $\left(<120{ }^{\circ} \mathrm{C}\right.$; Takai et al., 2008) or (ii) thermal degradation of organic matter at higher $\left(>150{ }^{\circ} \mathrm{C}\right)$ temperatures (Quigley and Mackenzie, 1988; Tang et al., 2000; Mango, 2001). The most widely accepted geochemical tool to determine the dominant sources of $\mathrm{CH}_{4}$ is based on both the composition of its stable isotopes $\left({ }^{13} \mathrm{C} /{ }^{12} \mathrm{C}\right.$ and $\left.{ }^{2} \mathrm{H} /{ }^{1} \mathrm{H}\right)(\mathrm{Schoell}, 1980)$ and the $\mathrm{CH}_{4} /\left(\mathrm{C}_{2} \mathrm{H}_{6}+\mathrm{C}_{3} \mathrm{H}_{8}\right)$ ratios (Bernard et al., 1978; Whiticar et al., 1986; Whiticar, 1999). Tassi et al. (2012) recently revisited this classical approach. These authors argued that $\mathrm{CH}_{4}$ production of most $\mathrm{CO}_{2}$-dominated gas discharges in peri-Tyrrhenian central Italy, including those from western SVD (Cinti et al., 2011), was related to $\mathrm{CO}_{2}$ reduction. This hypothesis was based on the observation that both the $\mathrm{CH}_{4} /$ $\left(\mathrm{C}_{2} \mathrm{H}_{6}+\mathrm{C}_{3} \mathrm{H}_{8}\right)$ ratios and $\delta^{13} \mathrm{C}-\mathrm{CH}_{4}$ values were much higher than those expected for a typical thermogenic $\mathrm{CH}_{4}$. Noteworthy, this $\mathrm{CH}_{4}$ genetic process cannot be recognized for the gas emissions from eastern SVD, since their $\delta^{13} \mathrm{C}_{-} \mathrm{CH}_{4}, \delta \mathrm{D}-\mathrm{CH}_{4}$, and $\mathrm{CH}_{4} /\left(\mathrm{C}_{2} \mathrm{H}_{6}+\mathrm{C}_{3} \mathrm{H}_{8}\right)$ values are consistent with a prevailing thermogenic source (Fig. $7 \mathrm{a}$ and $b$ ).

\subsubsection{Inert gas species}

Helium, $\mathrm{Ar}$ and $\mathrm{N}_{2}$ can be used as geochemical tracers to recognize primary fluid sources since they are chemically inert. As shown by the He-N2-Ar diagram (Fig. 8; Giggenbach, 1992), most gases from the eastern SVD plot close to the air or air-saturated water (ASW) composition, indicating relatively small extraatmospheric contribution for both $\mathrm{He}$ and $\mathrm{N}_{2}$. The latter, possibly related to reactions involving metasedimentary rocks (Honma and Itihara, 1981; Mingram and Brauer, 2001), is also suggested by the positive $\delta^{15} \mathrm{~N}-\mathrm{N}_{2}$ values (up to $+3.7 \%$ NBS air). On the contrary, the occurrence of dominant air-derived $\mathrm{Ar}$ is supported by the 


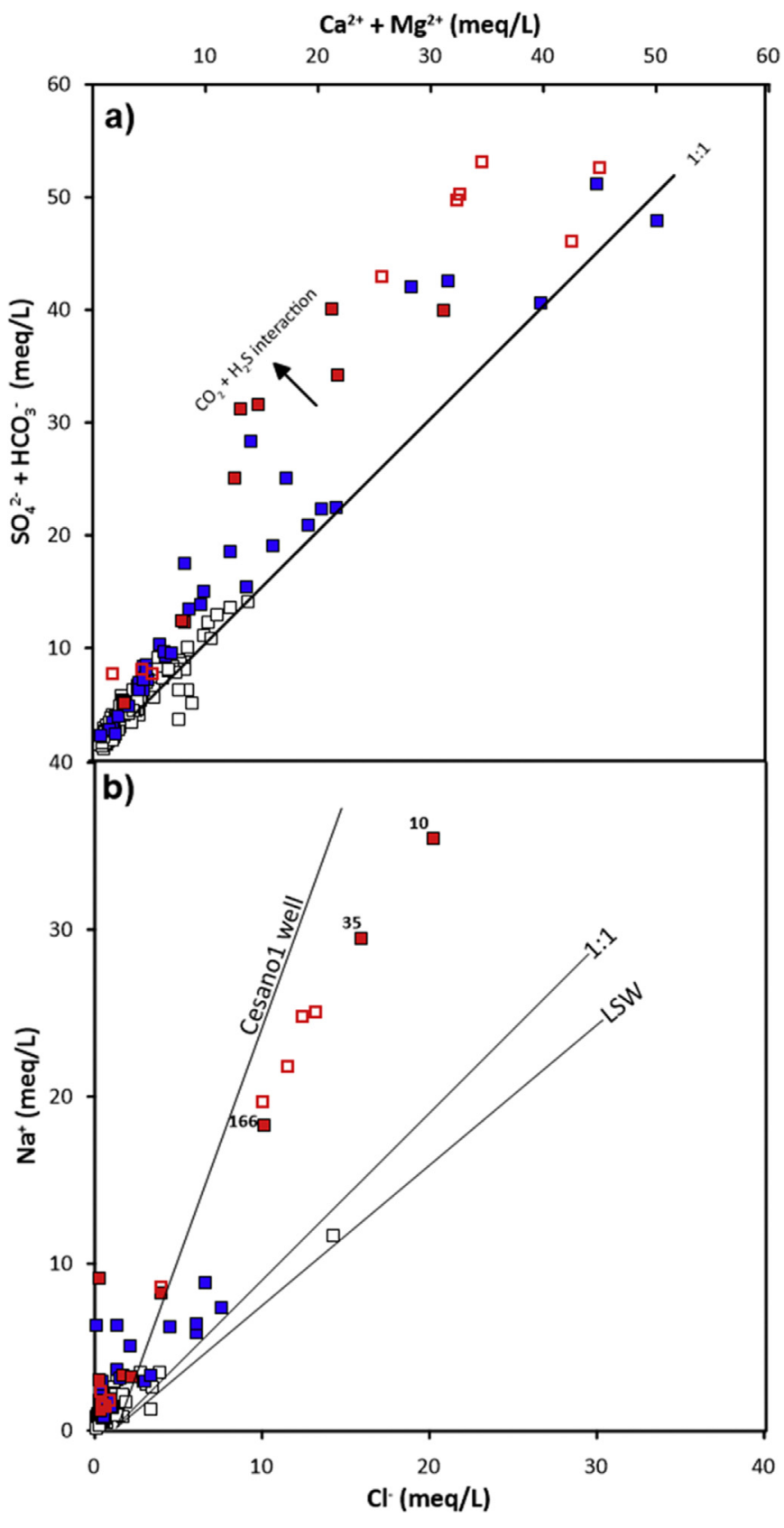

Fig. 5. a) $\mathrm{Ca}^{2+}+\mathrm{Mg}^{2+}$ vs. $\mathrm{SO}_{4}^{2-} / \mathrm{HCO}_{3}^{-}$and b) $\mathrm{Na}^{\mathrm{vs} . \mathrm{Cl}^{-}}$correlation plots for the collected waters. Samples of Stigliano (red open squares) are from Cinti et al. (2011). Symbols as in Fig. 2. (For interpretation of the references to colour in this figure legend, the reader is referred to the web version of this article.)

relatively low ${ }^{40} \mathrm{Ar} /{ }^{36} \mathrm{Ar}$ ratios (<305), i.e. close to atmospheric ratio (295.5; Marty, 1995). As far as the origin of He is concerned, the ${ }^{3} \mathrm{He} /{ }^{4} \mathrm{He}$ ratios can discriminate (i) ${ }^{4} \mathrm{He}-$ rich gases from radioactive decay processes, mostly occurring in the crust and typically producing $R / R_{a}$ values from 0.01 to 0.1 (O'Nions and Oxburgh, 1988), and (ii) ${ }^{3} \mathrm{He}$-rich gases related to a mantle source (Polyak and Tolstikhin, 1985). A pronounced northward decrease of the $R / R_{a}$ values in gas emissions (Hooker et al., 1985; Minissale, 2004) and fluid inclusions in olivine and clinopyroxene phenocrysts from the Quaternary rocks (Martelli et al., 2004) was observed from southern Italy (Mt. Etna and the Aeolian Islands) up to the Roman Magmatic Province. This feature was ascribed to mantle contamination via subduction of the Ionian-Adriatic plate beneath central-
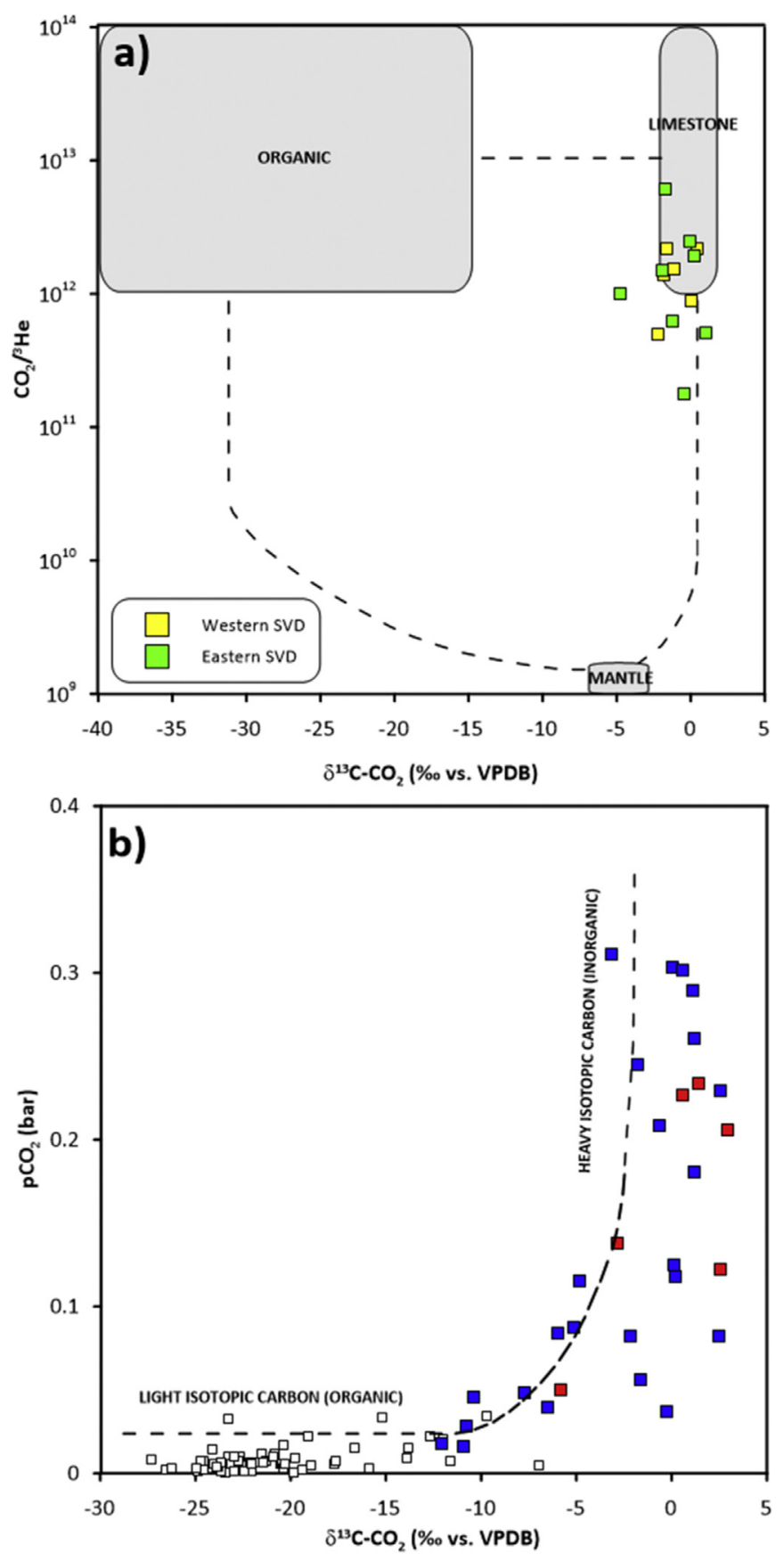

Fig. 6. a) $\mathrm{CO}_{2} /{ }^{3} \mathrm{He}$ vs. $\delta^{13} \mathrm{C}-\mathrm{CO}_{2}$ correlation plot for free gases. Boxes and mixing curves between the three end-members are from Sano and Marty (1995). Data for the western SVD gases are from Cinti et al. (2011); b) $\delta^{13} \mathrm{C}^{-} \mathrm{CO}_{2}$ in equilibrium with water vs. $\mathrm{pCO}_{2}$ (bar). Symbols as in Fig. 2.

southern Italy (Peccerillo, 1999; Martelli et al., 2004, 2008). The R/ $R_{a}$ ratios from the eastern SVD (from 0.07 to 1.04) are consistent with this general hypothesis, since they range within the values measured in gas emissions from the Roman Magmatic Province (Minissale, 2004; Barberi et al., 2007; Chiodini et al., 2007; Cinti et al., 2011) and are significantly lower than those found in the active volcanoes of southern Italy, e.g., 2.0-3.2 at Campi Flegrei, (Tedesco et al., 1990), 2.2-2.7 at Mt. Vesuvius (Federico et al., 2002), 6.5-6.9 at Mt. Etna (Allard et al., 1997; Tedesco, 1997). The eastern SVD isotopic values reflect a prevailing crustal-radiogenic source with a minor amount of mantle He. Assuming $\mathrm{R} / \mathrm{R}_{\mathrm{a}} \sim 6.5$ as the 


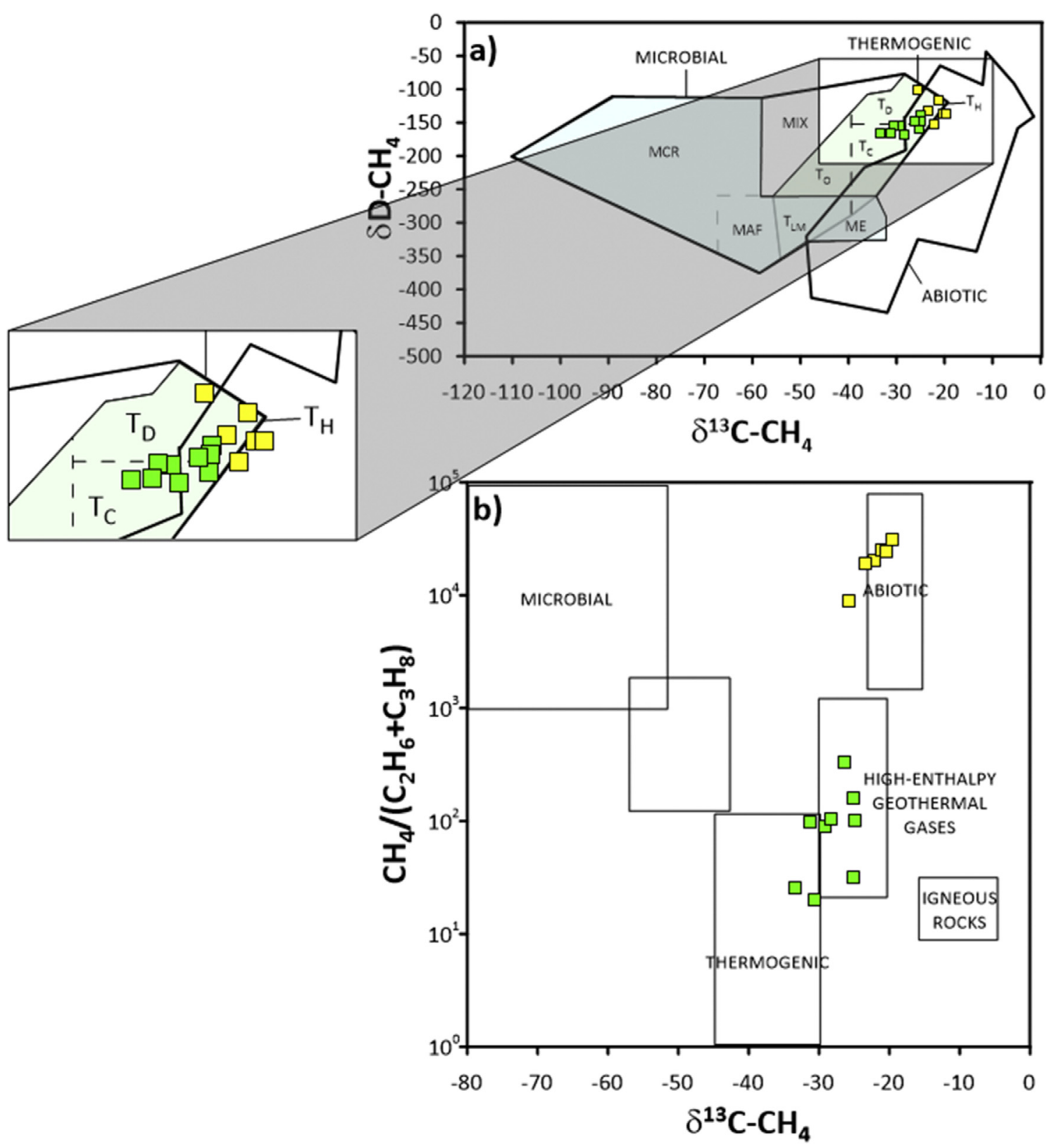

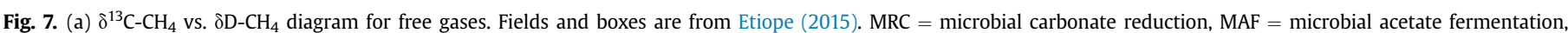

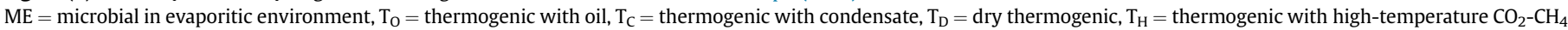

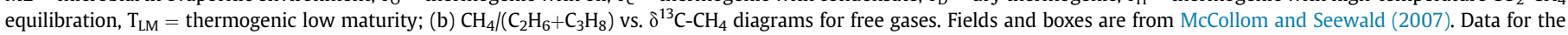
western SVD gases are from Cinti et al. (2011). Symbols as in Fig. 6a.

mantle end-member in central-southern Italy (Tedesco, 1997), i.e. similar to the European sub-continental mantle (Dunai and Baur, 1995), the mantle He fraction in the study area is estimated at $0.8-16 \%$.

\subsubsection{Reduced inorganic gases $\left(\mathrm{H}_{2} \mathrm{~S}\right.$ and $\left.\mathrm{H}_{2}\right)$}

Hydrogen sulfide in volcanic gas discharges is mainly produced by disproportionation of $\mathrm{SO}_{2}$ (Giggenbach, 1987; Allard et al., 1991; Oppenheimer et al., 2014), whereas sedimentary sources of $\mathrm{H}_{2} \mathrm{~S}$ consist of: 1) alteration of sulfide minerals (e.g. pyrite; Giggenbach, 1980; Chiodini, 1994), 2) microbial activity (Thode, 1991) and 3) thermo-chemical sulfate reduction (Machel et al., 1995; Worden and Smalley, 1996). Hydrothermal gases are characterized by the virtual absence of $\mathrm{SO}_{2}$ and the presence of $\mathrm{H}_{2} \mathrm{~S}$ as unique $\mathrm{S}$-bearing gaseous species (Giggenbach, 1980), whose origin can usefully be investigated by using the $\delta^{34} \mathrm{~S}-\mathrm{H}_{2} \mathrm{~S}$ values (e.g., Ault and Kulp, 1959; Sakai, 1968; Marini et al., 2011). The strongly positive $\delta^{34} \mathrm{~S}-\mathrm{H}_{2} \mathrm{~S}$ values of the eastern SVD gases (from 9.5 to $10.6 \%$ V-CDT) suggest to discard a $\mathrm{H}_{2} \mathrm{~S}$ volcanic source, since the $\delta^{34} \mathrm{~S}$ of magma-derived sulfur in volcanic rocks and gases is $\sim 0 \% \mathrm{~V}$-CDT (Allard et al., 1991; de Moor et al., 2013). It is worth mentioning that the $\delta^{34} S$ values of sulfide deposits in the SVD are mainly negative (averaging -2.6\% V-CDT; Cavarretta and Lombardi, 1992), whereas evaporitic sulfates from Triassic anhydrites (Burano Fm.) have $\delta^{34} \mathrm{~S}$ values ranging from 13.6 to $17.4 \%$ V-CDT (Cortecci et al., 1981), and the $\delta^{34} \mathrm{~S}_{-} \mathrm{SO}_{4}^{2-}$ values in Ca-SO 4 thermal waters are typically $~+14 \%$ V-CDT (Zuppi et al., 1974; Cavarretta and Lombardi, 1992; Cinti et al., 2014). Hence, $\mathrm{H}_{2} \mathrm{~S}$ in the eastern SVD gases likely derives from thermo-chemical reduction of anhydrites, according to reactions involving $\mathrm{CO}_{2}$ and $\mathrm{CH}_{4}$, as follows (Giggenbach, 1980; 


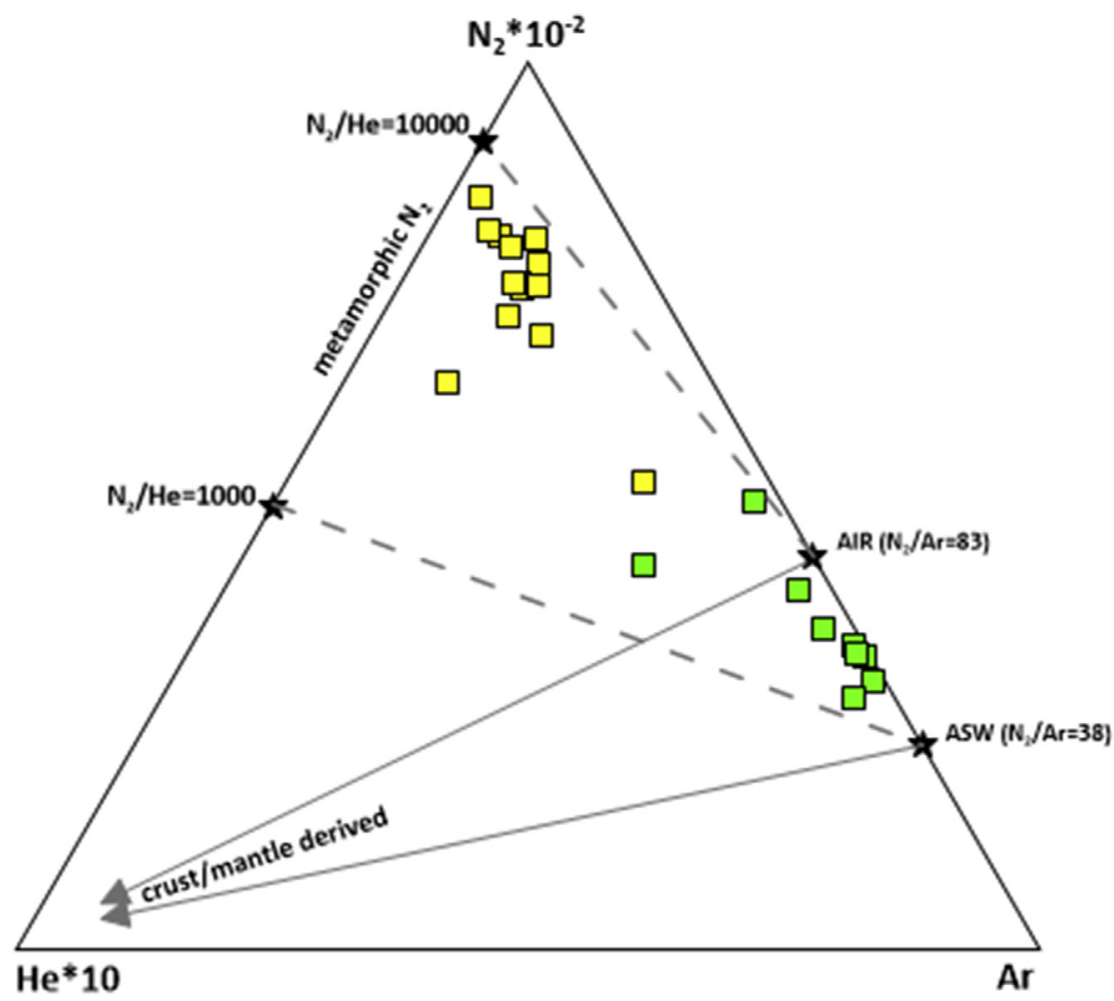

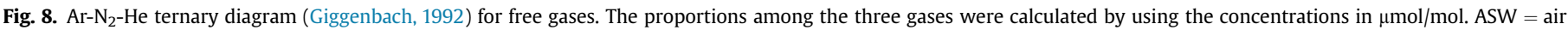
saturated water at $20^{\circ} \mathrm{C}$. Data for the western SVD gases are from Cinti et al. (2011). Symbols as in Fig. 6 a.

Worden and Smalley, 1996):

$\mathrm{CaSO}_{4}+\mathrm{CO}_{2}+4 \mathrm{H}_{2} \leftrightarrow \mathrm{CaCO}_{3}+\mathrm{H}_{2} \mathrm{~S}+3 \mathrm{H}_{2} \mathrm{O}$

$\mathrm{CaSO}_{4}+\mathrm{CH}_{4} \leftrightarrow \mathrm{CaSO}_{3}+\mathrm{H}_{2} \mathrm{~S}+\mathrm{H}_{2} \mathrm{O}$

It is worth noting that the $\delta^{34} \mathrm{~S}-\mathrm{H}_{2} \mathrm{~S}$ values isotopic values of the SVD gases are slightly lower than those of the evaporitic sulfates $(2-6 \%$ ). This implies that the isotopic fractionation affecting $\mathrm{S}$ during the reactions (5) and (6) occurs at relatively high temperatures $\left(\geq 200{ }^{\circ} \mathrm{C}\right)$ (Ohmoto and Rye, 1979; Machel et al., 1995). Accordingly, the source region of $\mathrm{H}_{2} \mathrm{~S}$ in the study area corresponds to the main hydrothermal reservoir where temperatures of $\sim 300^{\circ} \mathrm{C}$ were measured (Allegrini et al., 1982). By assuming this hypothesis as valid, $\mathrm{CH}_{4}$ and $\mathrm{H}_{2}$ likely originate within the same deep fluid reservoir, being involved in the reactions (5) and (6).

\subsubsection{Gas geothermometry}

The temperatures of a hydrothermal fluid reservoir can be estimated by applying a variety of geothermometers based on the chemical composition of gas discharges (e.g. Giggenbach, 1987; Chiodini and Marini, 1998). Since the eastern SVD gases are associated with bubbling pools, the concentrations of water vapor and CO mostly depend on interaction with liquid water at the surface, and therefore only low soluble gas compounds, such as $\mathrm{CH}_{4}, \mathrm{CO}_{2}$ and $\mathrm{H}_{2}$, can be used for geothermometric applications. Gas equilibria in the $\mathrm{CH}_{4}-\mathrm{CO}_{2}-\mathrm{H}_{2}$ system are controlled by the following reaction (Giggenbach, 1987, 1996):

$\mathrm{CH}_{4}+2 \mathrm{H}_{2} \mathrm{O} \leftrightarrow \mathrm{CO}_{2}+4 \mathrm{H}_{2}$

As shown in the $\log \left(\mathrm{XH}_{2} / \mathrm{XAr}^{*}\right)$ vs. $\log \left(\mathrm{XCH}_{4} / \mathrm{XCO}_{2}\right)$ binary diagram (Fig. 9), where the $\mathrm{Ar}^{*}$ values $\left(\mathrm{Ar}^{*}=\mathrm{Ar}-\mathrm{O}_{2} / 22\right.$, since the $\mathrm{O}_{2} / \mathrm{Ar}$ ratio in air is 22) is used to minimize the effect of air contamination occurring at the surface, the eastern SVD gases plot along the equilibrium curve of a liquid phase at redox conditions fixed by the D'Amore and Panichi (1980) buffer. Under these redox conditions, which are typical for hydrothermal fluids, the estimated temperatures of the eastern SVD gases range from 100 to $200{ }^{\circ} \mathrm{C}$, i.e. values considerably lower than those measured in the geothermal wells $\left(\sim 300{ }^{\circ} \mathrm{C}\right)$. The most reliable explanation is that re-equilibrium processes at lower temperatures affect $\mathrm{H}_{2}$ and $\mathrm{CH}_{4}$ during the uprising of fluids from the hydrothermal reservoir. However, the wide variations ( 2 log-units) of both the $\mathrm{XH}_{2} / \mathrm{XAr}^{*}$ and the $\mathrm{XCH}_{4} / \mathrm{XCO}_{2}$ ratios suggest that the concentrations of these gases are mostly depending on other processes than reaction (7). For example, the $\mathrm{CH}_{4} /\left(\mathrm{C}_{2} \mathrm{H}_{6}+\mathrm{C}_{3} \mathrm{H}_{8}\right)$ ratios and $\delta^{13} \mathrm{C}-\mathrm{CH}_{4}$, and $\delta \mathrm{D}-\mathrm{CH}_{4}$ values indicate that $\mathrm{CH}_{4}$ is dominantly produced by thermal degradation of organic matter, thus the behavior of this organic gas cannot be considered exclusively controlled by $\mathrm{CO}_{2}$ reduction.

A further exercise to provide insights into the fluid temperatures at depth can be carried out considering the $\mathrm{H}_{2} \mathrm{~S}-\mathrm{H}_{2}-\mathrm{H}_{2} \mathrm{O}$ system, as described by the following reaction (Chiodini et al., 2001):

$\mathrm{FeS}_{2}+\mathrm{H}_{2} \mathrm{O}_{(\text {vap })}+\left[\mathrm{H}_{2} \mathrm{O}\right] \leftrightarrow[\mathrm{FeO}]+\frac{1}{2} \mathrm{O}_{2}+2 \mathrm{H}_{2} \mathrm{~S}$

where [ $\mathrm{FeO}]$ is an unspecified $\mathrm{Fe}-\mathrm{Al}$ silicate and $\left[\mathrm{H}_{2} \mathrm{O}\right]$ the corresponding Al-silicate in its protonated, Fe-free, form. As already mentioned, the concentration of water vapor in the gases from the bubbling pools is controlled the condensation at the surface, thus calculations of gas equilibria in the $\mathrm{H}_{2} \mathrm{~S}-\mathrm{H}_{2}-\mathrm{H}_{2} \mathrm{O}$ system are carried out using the $\mathrm{H}_{2} \mathrm{O}_{\text {vap }}$ concentrations computed on the basis of the gas-water ratio $\left(\mathrm{X}_{\mathrm{g}}\right)$ that is estimated, as follows (Taran, 2005):

$X_{g}=\frac{0.0015}{A r}-0.0011 P_{t}$

where $P_{t}$, i.e. the air pressure at the recharge altitude, is 


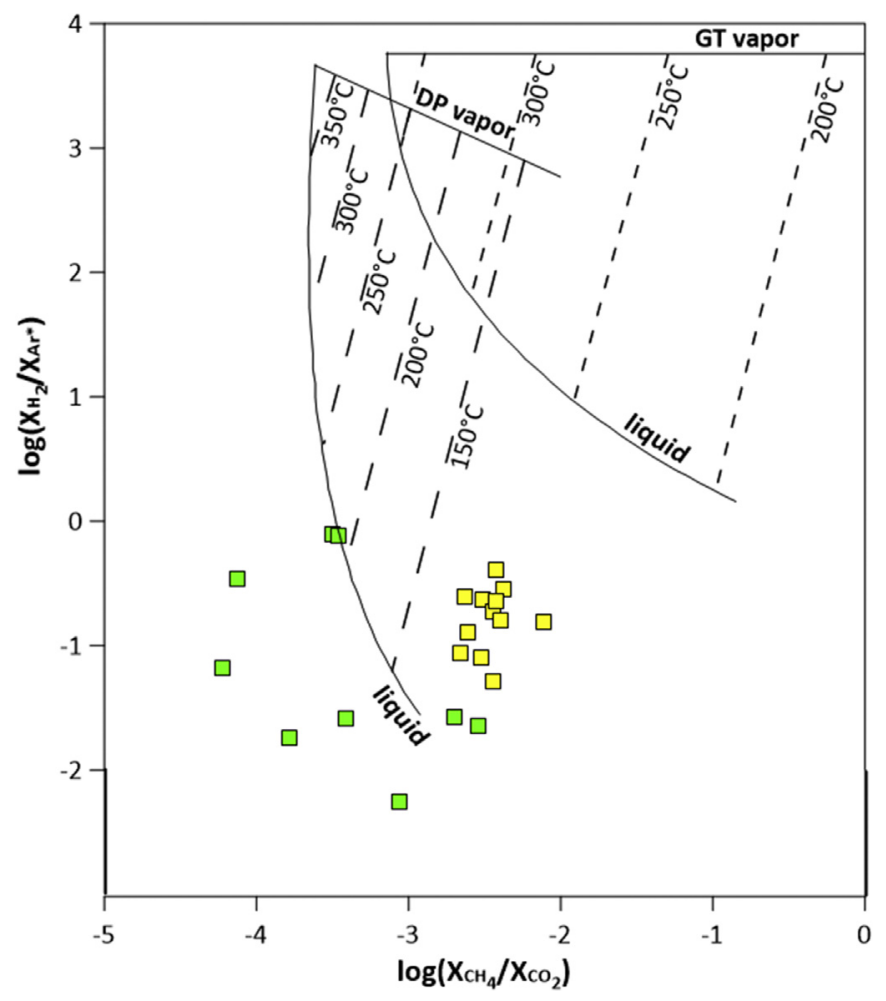

Fig. 9. Plot of $\log \left(\mathrm{X}_{\mathrm{CH} 4} / \mathrm{X}_{\mathrm{CO} 2}\right) \mathrm{vs} \log \left(\mathrm{X}_{\mathrm{H} 2} / \mathrm{X}_{\mathrm{Ar}^{*}}\right)$. The theoretical grids assume that redox conditions in the gas equilibration zone are controlled by the $\mathrm{FeO}-\mathrm{FeO}_{1.5}$ hydrothermal buffer (Giggenbach, 1987) and the DP buffer (D'Amore and Panichi, 1980). Data for the western SVD gases are from Cinti et al. (2011). Symbols as in Fig. 6a.

$0.878 \mathrm{~atm}$ at $10{ }^{\circ} \mathrm{C}$ and $1000 \mathrm{~m}$ a.s.l., and $\mathrm{Ar}$ is assumed as entirely atmospheric. The relatively large variation of the $\mathrm{XH}_{2} \mathrm{~S} / \mathrm{XH}_{2} \mathrm{O}$ ratios $(\sim 2$ log-units $)$ in the $\log \left(\mathrm{XH}_{2} \mathrm{~S} / \mathrm{XH}_{2} \mathrm{O}\right)$ vs. $\log \left(\mathrm{XH}_{2} / \mathrm{XH}_{2} \mathrm{O}\right)$ binary diagram (Fig. 4S) coupled with the significantly lower equilibrium temperatures with respect to those measured in geothermal wells, confirms that secondary processes, i.e. loss of $\mathrm{H}_{2} \mathrm{~S}$ due to its relatively high solubility and oxidation in the liquid phase, likely affect the deep gases during their ascent.

\section{Eastern vs. western SVD}

Although fluid discharges from the eastern and the western sectors of SVD are considered to pertain to a unique hydrothermal system (Fig. 10), the chemical and isotopic compositions of waters and gases from the two sectors show some significant differences.

Thermal waters showing relatively high $\mathrm{Na}^{+}$and $\mathrm{Cl}^{-}$concentrations occur in both the eastern and the western SVD, although only in the western sector (i.e. at Stigliano; Cinti et al., 2011) they are associated with high $\mathrm{NH}_{4} / \mathrm{Cl}, \mathrm{B} / \mathrm{Cl}$ and $\mathrm{Li} / \mathrm{Cl}$ ratios and to a marked ${ }^{18} \mathrm{O}$ enrichment, as related to fluids contribution from a deep geothermal brine. Moving eastward, the significantly lower $\mathrm{NH}_{4}^{+}$concentrations and $\mathrm{B} / \mathrm{Cl}$ and $\mathrm{Li} / \mathrm{Cl}$ ratios (Fig. 2Sb,c) and the meteoric signature of the $\mathrm{Na}$-Cl-rich thermal waters, suggest that the most reliable source of these compounds likely consist of highly saline waters locally trapped in the Neogene marine sediments. Some contribution from a deep $\mathrm{Na}-\mathrm{Cl}$ geothermal brine, as that intercepted by geothermal wells at Cesano, seems unlike, although it cannot completely be ruled out.

With respect to the gas emissions, those discharging from the eastern SVD, showing relatively high $\mathrm{N}_{2}$ and $\mathrm{Ar}$ concentrations (Table 1), and low $\mathrm{N}_{2} / \mathrm{Ar}$ (Fig. 8) and $\delta^{15} \mathrm{~N}-\mathrm{N}_{2}$ values (Table 1), are marked by a higher contribution from air with respect to the western SVD gases. Accordingly, equilibrium temperature estimations computed according to both the $\mathrm{CH}_{4}-\mathrm{CO}_{2}-\mathrm{H}_{2}$ and the $\mathrm{H}_{2} \mathrm{~S}-\mathrm{H}_{2}-$ $\mathrm{H}_{2} \mathrm{O}$ geothermometers for the eastern SVD gases are not reliable since they show too large variations. On the contrary, computed temperatures by using the same theoretical approach for the gases from the western SVD sector (Cinti et al., 2011) cluster around at $\sim 175^{\circ} \mathrm{C}$, although significantly lower than those measured at depth. A further important distinction in the fluid chemistry of the two areas is highlighted by the $\mathrm{C}_{1} / \mathrm{C}_{2}$ ratios and $\delta^{13} \mathrm{C}_{-}-\mathrm{CH}_{4}$ and $\delta \mathrm{D}-\mathrm{CH}_{4}$ values (Fig. 7): the eastern SVD gases show the typical features of thermogenic $\mathrm{CH}_{4}$, whereas $\mathrm{CO}_{2}$ reduction is the main production mechanism of $\mathrm{CH}_{4}$ in the gas emissions from western SVD (Cinti et al., 2011).

Summarizing, fluids from the western and the eastern sectors of SVD show some significant differences, mainly due to a higher contribution of shallow secondary processes in the eastern SVD, which are able to significantly mask the chemistry of the uprising deep fluids. One possible explanation for this spatial compositional distribution is that the cooling and diluting effects of meteoric water from the Apennine chain are particularly efficient in the easternmost fluid discharges, since they are closer to this important recharge area with respect to those emerging in the westernmost ones. The enhanced contribution of meteoric water to the uprising hydrothermal fluids also produces the relatively high air contamination characterizing the eastern SVD gases.

\section{Conclusions}

The SVD hosts a water-dominated hydrothermal reservoir at $\mathrm{T} \sim 300{ }^{\circ} \mathrm{C}$ that discharges $\mathrm{Ca}-\mathrm{HCO}_{3}\left(\mathrm{SO}_{4}\right)$ to $\mathrm{Na}(\mathrm{Ca})-\mathrm{HCO}_{3}(\mathrm{Cl})$ waters, mostly emerging along the borders of buried horst-graben structures, where extensional fractures and faults provide permeable pathways for their ascent to the surface (Fig. 10). A $\mathrm{CO}_{2}\left(\mathrm{H}_{2} \mathrm{~S}\right)$-rich gas phase is occasionally associated with the thermal fluid discharges, although the frequent occurrence of $\mathrm{CO}_{2}$-rich cold waters

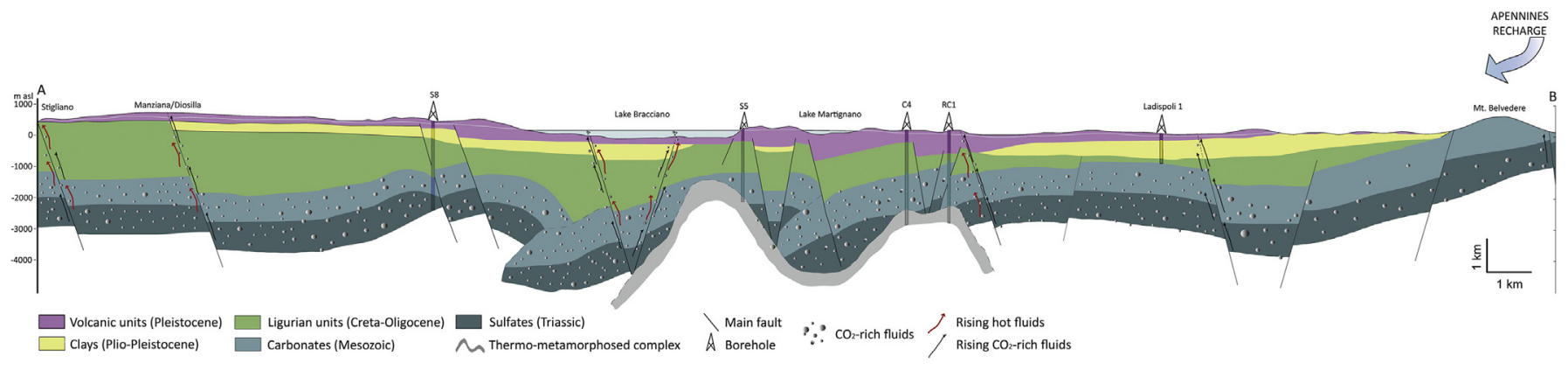

Fig. 10. Interpretative conceptual model of groundwater circulation in the Sabatini Volcanic District. 
(acque acetose) indicates that a significant amount of deeporiginated gases is discharged through diffuse soil degassing. The isotopic signature of $\mathrm{CO}_{2}$ and He suggests that these gases mainly have a crustal origin with minor contribution from mantle degassing. Cold $\mathrm{Ca}(\mathrm{Na})-\mathrm{HCO}_{3}$ waters are not affected by the hydrothermal system, being located far from the main tectonic alignments. Hence, in the absence of tectonic disturbance, the shallow volcanic and sedimentary formations efficiently isolate the hydrothermal reservoir from the surface. Meteoric waters from local highs and the Apennine range recharge both the shallow and deep reservoirs. By comparing the hydrothermal fluids discharging in the western and eastern sector of SVD, the latter are strongly influenced at relatively shallow depth by the cold and air-rich meteoric water recharge from the Apennine range. No clear clues of the $\mathrm{Na}-\mathrm{Cl}$ brine discharged from the Cesano geothermal wells are recognized at the surface, even where the tectonic setting locally favors the uprising of the hydrothermal fluids. Although masked by mixing processes with the shallow aquifer, the deep hydrothermal reservoir of eastern SVD is to be considered an important potential resource, especially considering the recent renewed interest for geothermal energy in Italy. In the past the exploitation through conventional technologies was strongly limited by the fluid characteristics (i.e. high salinity of the liquid phase and presence of corrosive gases). Presently, the most recent unconventional technologies can make possible the exploitation of the geothermal resources through binary systems where a working fluid, generally constituted by organic compounds (propane), is used in place of the geothermal fluid to produce electricity (Di Pippo, 2008). Moreover, direct uses (e.g. building heating and cooling, fish farming, greenhouse heating), which imply relatively low costs, may represent, at a local scale, more than a valid alternative for the exploitation of these thermal fluids.

\section{Acknowledgements}

All the municipalities of the eastern SVD are warmly thanked for their help during the extensive field work. A special thank is due to the staff of the Natural Parks whose territories are within the study area (i.e. Parco Regionale di Veio, Parco Regionale di BraccianoMartignano and Parco Regionale Valle del Treja). Dr. D. Tedesco and an anonymous reviewer are warmly thanked for their helpful and useful suggestions on an early version of the manuscript.

\section{Appendix A. Supplementary data}

Supplementary data related to this article can be found at http:// dx.doi.org/10.1016/j.apgeochem.2017.06.014.

\section{References}

Acocella, V., Funiciello, R., 2006. Transverse systems along the extensional Tyrrhenian margin of central Italy and their influence on volcanism. Tectonics 25 . http://dx.doi.org/10.1029/2005TC001845.

Allard, P., Maiorani, A., Tedesco, D., Cortecci, G., Turi, B., 1991. Isotopic study of the origin of sulfur and carbon in Solfatara fumaroles, Campi Flegrei caldera. J. Volcanol. Geotherm. Res, 48, 139-159.

Allard, P., Jean-Baptiste, P., D'Alessandro, W., Parello, F., Parisi, B., Flehoc, C., 1997. Mantle derived helium and carbon in groundwater and gases of Mount Etna. Italy. Earth Planet. Sci. Lett. 148, 501-516.

Allegrini, G., Corsi, R., Culivicchi, G., Di Falco, R., Fiordelisi, A., Grassi, A., Nardini, G., Nencetti, G.F., Tomei, B., 1982. Fluid management of the Cesano reservoir: experimental activity. In: proceedings of the $1^{\text {st }}$ Turkish-Italian seminar on geothermal energy, Ankara and Kizildere, Turkey, Sept. 6-28, 1982. Comp. Exam. Kizildere Cesano Geotherm. Fields II, 143-206.

Arnorsson, S., Gunnlaugsson, E., Svavarsson, H., 1983. The chemistry of geothermal waters in Iceland - II. Mineral equilibria and independent variables controlling water compositions. Geochim. Cosmochim. Acta 47, 547-566.

Ault, W.U., Kulp, J.L., 1959. Isotopic geochemistry of sulphur. Geochim. Cosmochim. Acta $16,201-235$.
Baldi, P., Ferrara, G.C., Masselli, L., Pieretti, G., 1973. Hydrogeochemistry of the region between monte amiata and Rome. Geothermics 2, 124-141.

Barberi, F., Buonasorte, G., Cioni, R., Fiordalisi, A., Foresi, L., Iaccarino, S., Laurenzi, M.A., Sbrana, A., Vernia, L., Villa, I.M., 1994. Plio-Pleistocene geological evolution of the geothermal area of Tuscany and Latium. Mem. Descr. della Carta Geol. d'Italia 49, 77-134.

Barberi, F., Carapezza, M.L., Ranaldi, M., Tarchini, L., 2007. Gas blowout from shallow boreholes at Fiumicino (Rome): induced hazard and evidence of deep $\mathrm{CO}_{2}$ degassing on the Tyrrhenian margin of central Italy. J. Volcanol. Geotherm. Res. $165,17-31$.

Barbieri, M., Boschetti, T., Petitta, M., Tallini, M., 2005. Stable isotope $\left({ }^{2} \mathrm{H},{ }^{18} \mathrm{O}\right.$ and $\left.{ }^{87} \mathrm{Sr} /{ }^{86} \mathrm{Sr}\right)$ and hydrochemistry monitoring for groundwater hydrodynamics analysis in a karst aquifer (Gran Sasso, central Italy). Appl. Geochem 20, 2063-2081.

Barbieri, M., Masi, U., Tolomeo, L., 1979. Origin and distribution of strontium in the travertines of Latium (central Italy). Chem. Geol. 24, 181-188.

Bernard, B.B., Brooks, J.M., Sackett, W.M., 1978. A Geochemical Model for Characterization of Hydrocarbon Gas Sources in Marine Sediments. Proc. of the Offshore Technology Conference, Houston, USA, pp. 435-438.

Billi, B., Cappetti, G., Luccioli, F., 1986. ENEL activity in the research, exploration and exploitation of geothermal energy in Italy. Geothermics 15, 765-779.

Buonasorte, G., Carboni, M.G., Conti, M.A., 1991. Il substrato plio-pleistocenico delle vulcaniti sabatine: considerazioni stratigrafiche e paleoambientali. Boll. Soc. Geol. It 110, 35-40.

Buonasorte, G., Cameli, G.M., Fiordalisi, A., Parotto, M., Perticone, I., 1995. Results of Geothermal Exploration in Central Italy (Latium-campania). Proc. of the World Geothermal Congress, Florence, Italy, pp. 1293-1298.

Calamai, A., Cataldi, R., Dall'Aglio, M., Ferrara, G.C., 1976. Preliminary report on the Cesano hot brine deposit (Northern Latium, Italy). Proc. U.N. Symp. Development Use Geotherm. Energy, S. Francisco, USA 305-313.

Capasso, G., Inguaggiato, S., 1998. A simple method for the determination of dissolved gases in natural waters. Appl. Therm. waters Vulcano Isl. Appl. Geochem $13,631-642$.

Capelli, G., Mazza, R., Gazzetti, C., 2005. In: Pitagora (Ed.), Strumenti e strategie per la tutela e l'uso compatibile della risorsa idrica nel Lazio: gli acquiferi vulcanici, p. 191.

Cartwright, I., Weaver, T., Tweed, S., Ahearne, D., Cooper, M., Czapnik, K., Tranter, J. 2002. Stable isotope geochemistry of cold $\mathrm{CO}_{2}$-bearing mineral spring waters, Daylesford, Victoria, Australia: sources of gas and water and links with waning volcanism. Chem. Geol. 185, 71-91.

Cavarretta, G., Lombardi, G., 1992. Origin of sulphur in minerals and fluids from Latium (Italy): isotopic constraints. Eur. J. Mineral. 4, 1311-1329.

Cavarretta, G., Tecce, F., 1987. Contact metasomatic and hydrothermal minerals in the SH2 well, Sabatini volcanic district, Latium, Italy. Geothermics 2, 127-145.

Cerling, T.E., Solomon, D.K., Quade, J., Bowman, J.R., 1991. On the isotopic composition of carbon in soil carbon dioxide. Geochim. Cosmochim. Acta 55, 3403-3405.

Chiodini, G., 1994. Temperature, pressure and redox conditions governing the composition of the cold $\mathrm{CO}_{2}$ gases discharged in north Latium (central Italy). Appl. Geochem 9, 287-295.

Chiodini, G., Baldini, A., Barberi, F., Carapezza, M.L., Cardellini, C., Frondini, F. Granieri, D., Ranaldi, M., 2007. Carbon dioxide degassing at Latera caldera (Italy): evidence of geothermal reservoir and evaluation of its potential energy. J. Geophys. Res. 112 http://dx.doi.org/10.1029/2006JB004896.

Chiodini, G., Frondini, F., Cardellini, C., Parello, F., Peruzzi, L., 2000. Rate of diffuse dioxide carbon Earth degassing estimated from carbon balance of regional aquifers: the case of central Apennine. Italy. J. Geophys. Res. 105, 8423-8434.

Chiodini, G., Frondini, F., Kerrick, D.M., Rogie, J., Parello, F., Peruzzi, L., Zanzari, A.R., 1999. Quantification of deep $\mathrm{CO}_{2}$ fluxes from central Italy. Examples of carbon balance for regional aquifers and of soil diffuse degassing. Chem. Geol. 159, 205-222.

Chiodini, G., Marini, L., 1998. Hydrothermal gas equilibria: the $\mathrm{H}_{2} \mathrm{O}-\mathrm{H}_{2}-\mathrm{CO}_{2}-\mathrm{CO}-\mathrm{CH}_{4}$ system. Geochim. Cosmochim. Acta 62, 2673-2687.

Chiodini, G., Marini, L., Russo, M., 2001. Geochemical evidence for the existence of high-temperature hydrothermal brines at Vesuvio volcano, Italy. Geochim. Cosmochim. Acta 65, 2129-2147.

Cimarelli, C., De Rita, D., 2006. Relatively rapid emplacement of dome-forming magma inferred from strain analyses: the case of the acid dome complexes (central Italy). J. Volcanol. Geotherm. Res. 158, 106-116.

Cinti, D., Procesi, M., Tassi, F., Montegrossi, G., Sciarra, A., Vaselli, O., Quattrocchi, F., 2011. Fluid geochemistry and geothermometry in the western sector of the Sabatini volcanic district and the Tolfa Mountains (Central Italy). Chem. Geol. 284, 160-181.

Cinti, D., Tassi, F., Procesi, M., Bonini, M., Capecchiacci, F., Voltattorni, N., Vaselli, O., Quattrocchi, F., 2014. Fluid geochemistry and geothermometry in the unexploited geothermal field of the Vicano-Cimino Volcanic District (Central Italy). Chem. Geol. 371, 96-114.

Cioni, R., Laurenzi, M.A., Sbrana, A., Villa, I.M., 1993. ${ }^{40} \mathrm{Ar}-{ }^{39} \mathrm{Ar}$ chronostratigraphy of the initial activity in the Sabatini Volcanic Complex (Italy). Boll. Soc. Geol. It 112, 251-263.

Cortecci, G., Reyes, E., Berti, G., Casati, P., 1981. Sulfur and oxygen isotopes in Italian marine sulfate of Permian and Triassic age. Chem. Geol. 34, 65-79.

Craig, H., 1961. Isotopic variations in meteoric waters. Science 133, 1702-1703.

Craig, H., 1963. The isotopic geochemistry of water and carbon in geothermal areas. In: Tongiorgi, E. (Ed.), Nuclear Geology on Geothermal Areas. CNR (Italian 
Council for Research), Spoleto, Italy, pp. 17-54.

Dall'Aglio, M., Duchi, V., Minissale, A., Guerrini, A., Tremori, M., 1994. Hydrogeochemistry of the volcanic district in the Tolfa and Sabatini Mountains in central Italy. J. Hydrol. 154, 195-217.

D'Amore, F., Panichi, C., 1980. Evaluation of deep temperature of hydrothermal systems by a new gas-geothermometer. Geochim. Cosmochim. Acta 44, 549-556.

Della Vedova, B., Pellis, G., Foucher, J.P., Rehault, J.P., 1984. Geothermal structure of Tyrrhenian sea. Mar. Geol. 55, 271-289.

de Moor, J.M., Fischer, T.P., Sharp, Z.D., King, P.L., Wilke, M., Botcharnikov, R.E., Cottrell, E., Zelenski, M., Marty, B., Klimm, K., Rivard, C., Ayalew, D., Ramirez, C., Kelly, K.A., 2013. Sulfur degassing at Erta Ale (Ethiopia) and Masaya (Nicaragua) volcanoes: implications for degassing processes and oxygen fugacities of volcanoes: implications for degassing processes and oxygen fugacities of
basaltic systems. Geochem. Geophys. Geosyst. http://dx.doi.org/10.1022/ ggge.20255.

De Rita, D., Di Filippo, M., Rosa, C., 1996. Structural evolution of the Bracciano volcano-tectonic depression, Sabatini volcanic district, Italy. In: McGuire, W.C., et al. (Eds.), Volcano Instability on the Earth and Other Planets, vol. 110. Geol. Soc. Spec. Publication, pp. 225-236.

De Rita, D., Cremisini, C., Cinnirella, A., Spaziani, F., 2011. Fluorine in the rocks and sediments of volcanic areas in central Italy: total content, enrichment and leaching processes and a hypothesis on the vulnerability of the related aquifers. Environ. Monit. Assess. http://dx.doi.org/10.1007/s10661-011-2381-3.

Deuser, W.G., Degens, E.T., 1967. Carbon isotope fractionation in the system $\mathrm{CO}_{2}$ (gas) $-\mathrm{CO}_{2}$ (aqueous) $-\mathrm{HCO}_{3}$ (aqueous). Nature 215, 1033-1035.

Di Pippo, R., 2008. Binary cycle power plants. In: Butterworth-Heinemann (Ed.), Geothermal Power Plant: Principles, Applications, Case Studies and Environmental Impact, pp. 157-184. Amsterdam.

Doglioni, C., Gueguen, E., Harabaglia, P., Mongelli, F., 1999. On the origin of West directed subduction zones and applications to the western Mediterranean. In: Durand, B., et al. (Eds.), The Mediterranean Basins: Tertiary Extensions within the Alpine Orogen, vol. 156. Geol. Soc. Spec. Publ., pp. 541-561

Duchi, V., Minissale, A., 1995. Distribuzione delle manifestazioni gassose nel settore peritirrenico Tosco-Laziale e loro interazione con gli acquiferi superficiali. Boll. della Soc. Geol. Ital. 114, 337-351.

Duchi, V., Minissale, A., Paolieri, M., Prati, F., Valori, A., 1992. Chemical relationship between discharging fluids in the Siena-Radicofani graben and deep fluids produced by the geothermal fields of Mt. Amiata, Torre Alfina and Latera (central Italy). Geothermics 21, 401-413.

Dunai, T.J., Baur, H., 1995. Helium, neon, and argon systematics of the European subcontinental mantle: implications for its geochemical evolution. Geochim. Cosmochim. Acta 59, 2767-2783.

Etiope, G., 2015. Natural Gas Seepage. Springer International Publishing, Switzerland. http://dx.doi.org/10.1007/978-3-319-14601-0.

Fazzini, P., Gelmini, L., Mantovani, M.P., Pellegrini, M., 1972. Geologia dei monti della Tolfa (Lazio settentrionale; prov. di Viterbo e Roma). Mem. Soc. Geol. It. 11, 65-144.

Federico, C., Aiuppa, A., Allard, P., Bellomo, S., Jean-Baptiste, P., Parello, F., Valenza, M., 2002. Magma-derived gas influx and water-rock interactions in the volcanic aquifer of Mt. Vesuvius. Italy. Geochim. Cosmochim. Acta 66, 963-981.

Funiciello, R., Mariotti, G., Parotto, M., Preite-Martinez, M., Tecce, F., Toneatti, R., Turi, B., 1979. Geology, mineralogy and stable isotope geochemistry of the Cesano geothermal field (Sabatini Mountains, Northern Latium, Italy). Geothermics 8, 55-73.

Gambardella, B., Marini, L., Baneschi, I., 2005. Dissolved potassium in the shallow groundwaters circulating in the volcanic rocks of central-southern Italy. Appl. Geochem 20, 875-897.

Gat, J.R., Carmi, I., 1970. Evolution of the isotopic composition of atmospheric waters in the Mediterranean Sea area. J. Geophys. Res. 75, 3039-3048.

Giggenbach, W.F., 1980. Geothermal gas equilibria. Geochim. Cosmochim. Acta 44, 2021-2032.

Giggenbach, W.F., 1987. Redox processis governing the chemistry of fumarolic gas discharges from White Island. New Zeal. Appl. Geochem 2, 143-161.

Giggenbach, W.F., 1988. Geothermal solute equilibria. Derivation of Na-K-Ca-Mg geoindicators. Geochim. Cosmochim. Acta 52, 2749-2765.

Giggenbach, W.F., 1992. The composition of gases in geothermal and volcanic systems as a function of tectonic setting. Proc. Int. Symposium Water-Rock Interact. WRI-8 873-878.

Giggenbach, W.F., 1996. Chemical composition of volcanic gases. In: Scarpa, R. Tilling, R.I. (Eds.), Monitoring and Mitigation of Volcano Hazards. Springer, pp. $221-256$.

Giggenbach, W.F., Goguel, R.L., 1989. Method for the Collection and Analysis of Geothermal and Volcanic Water and Gas Samples, vol. 2387, p. 53. NZ-DSIR Report, CD.

Honma, H., Itihara, Y., 1981. Distribution of ammonium in minerals of metamorphic and granitic rocks. Geochim. Cosmochim. Acta 13, 225-232.

Hooker, P.J., Bertrami, R., Lombardi, S., O'Nions, R.K., Oxburgh, E.R., 1985. Helium-3 anomalies and crust-mantle interaction in Italy. Geochim. Cosmochim. Acta 49, $2505-2513$.

Javoy, M., Pineau, F., Allegre, C.J., 1982. Carbon geodynamic cycle. Nature 300, $171-173$.

Karner, D.B., Marra, F., Renne, P.R., 2001. The history of the Monti Sabatini and Alban Hills volcanoes: groundwork for assessing volcanic-tectonic hazards for Rome. J. Volcanol. Geotherm. Res. 107, 185-219.

Longinelli, A., Selmo, E., 2003. Isotopic composition of precipitation in Italy: a first overall map. J. Hydrol. 270, 75-88.

Machel, H.G., Krouse, H.R., Sassen, R., 1995. Products and distinguishing criteria of bacterial and thermochemical sulphate reduction. Appl. Geochem 10, 373-389.

Mamyrin, B.A., Tolstikhin, I.N., 1984. Helium Isotopes in Nature. Elsevier, Amsterdam.

Mango, F.D., 2001. Methane concentrations in natural gas: the genetic implications. Org. Geochem 32, 1283-1287.

Marini, L., Moretti, R., Accornero, M., 2011. Sulfur isotopes in magmatichydrothermal systems, melts, and magmas. Rev. Mineral. Geochem 73, 423-492.

Martelli, M., Nuccio, P.M., Stuart, F.M., Burgess, R., Ellam, R.M., Italiano, F., 2004. Helium-strontium isotope constraints on mantle evolution beneath the Roman Comagmatic Province. Italy. Earth Planet. Sci. Lett. 224, 295-308.

Martelli, M., Nuccio, P.M., Stuart, F.M., Di Liberto, V., Ellam, R.M., 2008. Constraints on mantle source and interactions from He-Sr isotope variation in Italian PlioQuaternary volcanism. Geochem. Geophys 9. http://dx.doi.org/10.1029/ 2007GC001730.

Marty, B., 1995. Nitrogen content of the mantle inferred from $\mathrm{N}_{2}$-Ar correlation in oceanic basalts. Nature 337, 326-328.

Marty, B., Jambon, A., 1987. C/ ${ }^{3} \mathrm{He}$ in volatile fluxes from the solid Earth: implications, for carbon geodynamics. Earth Planet. Sci. Lett. 83, 16-26.

McCollom, T.M., Seewald, J.S., 2007. Abiotic synthesis of organic compounds in deep-sea hydrothermal environments. Chem. Rev. 107, 382-401.

Mingram, B., Brauer, K., 2001. Ammonium concentration and nitrogen isotope composition in metasedimentary rocks from different tectonometamorphic units of the European Variscan Belt. Geochim. Cosmochim. Acta 65, 273-288.

Minissale, A., 2004. Origin, transport and discharge of $\mathrm{CO}_{2}$ in Central Italy. Earth-Sci. Rev. 66, 89-141.

Minissale, A., Evans, W., Magro, G., Vaselli, O., 1997a. Multiple source components in gas manifestations from north-central Italy. Chem. Geol. 142, 175-192.

Minissale, A., Magro, G., Vaselli, O., Verrucchi, C., Perticone, I., 1997b. Geochemistry of waters and gas discharges from the Mt. Amiata silicic complex and surrounding areas (central Italy). J. Volcanol. Geotherm. Res. 79, 223-251.

Minissale, A., Vaselli, O., 2011. Karst springs as "natural" pluviometers: constraints on the isotopic composition of rainfall in the Apennines of central Italy. Appl. Geochem 26, 838-852.

Montegrossi, G., Tassi, F., Vaselli, O., Buccianti, A., Garofano, K., 2001. Sulfur species in volcanic gases. Anal. Chem. 73, 3709-3715.

Mook, W.G., Bommerson, J.C., Staverman, W.H., 1974. Carbon isotope fractionation between dissolved carbonate and gaseous carbon dioxide. Earth Planet. Sci. Lett. 22, 169-176.

Ohmoto, H., Rye, R.O., 1979. Isotopes of sulfur and carbon. In: Barnes, H.L. (Ed.), Geochemistry of Hydrothermal Ore Deposits, second ed. Wiley and Sons Ltd., Chichester, pp. 509-567.

O'Nions, R.K., Oxburgh, E.R., 1988. Helium volatile fluxes and the development of continental crust. Earth Planet. Sci. Lett. 90, 331-347.

Oppenheimer, C., Fischer, T.P., Scaillet, B., 2014. Volcanic Degassing: Process and Impact. In: Holland, H.D., et al. (Eds.). Elsevier, Pergamon, Oxford, pp. 111-179.

Ozima, M., Podosek, F.A., 2002. Noble gas Geochemistry, second ed. Cambridge University Press, Cambridge, UK, p. 286.

Parkhurst, D.L., Appelo, C.A.J., 2013. Description of input and examples for PHREEQC version 3-A computer program for speciation, batch-reaction, one-dimensional transport, and inverse geochemical calculations. U.S.G.S. Tech. Methods, book 6, chap. A43 497 available at: http://pubs.usgs.gov/tm/06/a43.

Peccerillo, A., 1985. Roman comagmatic province: evidence for subduction-related magma genesis. Geology 13, 103-106.

Peccerillo, A., 1999. Multiple mantle metasomatism in central-southern Italy: geochemical effects, timing and geodynamic implications. Geology 27, 315-318.

Polyak, B.G., Tolstikhin, I.N., 1985. Isotopic composition of the Earth's helium and the problem of tectonogenesis. Chem. Geol. 52, 9-33.

Poreda, R.J., Craig, H., 1989. Helium isotope ratios in circum-Pacific volcanic arcs. Nature 338, 473-478.

Procesi, M., Cantucci, B., Buttinelli, M., Armezzani, G., Quattrocchi, F., Boschi, E., 2013. Strategic use of the underground in an energy mix plan: synergies among $\mathrm{CO}_{2}, \mathrm{CH}_{4}$ geological storage and geothermal energy. Appl. Energy 110, 104-131.

Quigley, T.M., Mackenzie, A.S., 1988. The temperature of oil and gas formation in the sub-surface. Nature 333, 549-552.

Rizzo, A., Barberi, F., Carapezza, M.L., Di Piazza, A., Francalanci, L., Sortino, F., D'Alessandro, W., 2015. New mafic magma refilling a quiescent volcano; evidence from He-Ne-Ar isotopes during the 2011-2012 unrest at Santorini, Greece. Geochem. Geophys. Geosyst 16, 798-814.

Rollinson, H., 1993. Using Geochemical Data. Longman Group, London.

Rye, R.O., Bethke, P.M., Wasserman, M.D., 1992. The stable isotope geochemistry of acid sulphate alteration. Econ. Geol. Bull. Soc. 87, 225-261.

Sakai, H., 1968. Isotopic properties of sulfur compounds in hydrothermal processes. Geochim. J. 2, 29-49.

Salata, G.G., Roelke, L.A., Cifuentes, L.A., 2000. A rapid and precise method for measuring stable isotope ratios of dissolved inorganic carbon. Mar. Chem. 69, $153-161$.

Sano, Y., Marty, B., 1995. Origin of carbon in fumarolic gas from island arcs. Chem. Geol. 119, 265-274.

Schoell, M., 1980. The hydrogen and carbon isotopic composition of methane from natural gases of various origins. Geochim. Cosmochim. Acta 44, 649-661.

Scrocca, D., Doglioni, C., Innocenti, F., 2003. Constraints for an interpretation of the Italian geodynamics: a review. Mem. Descr. Carta Geol. D'It 62, 15-46. 
Takai, K., Nakamura, K., Toki, T., Tsunogai, U., Miyazaki, M., Miyazaki, J., Hirayama, H., Nakagawa, S., Nunoura, T., Horikoshi, K., 2008. Cell proliferation at $122^{\circ} \mathrm{C}$ and isotopically heavy $\mathrm{CH}_{4}$ production by a hyperthermophilic methanogene under high-pressure cultivation. PNAS 105, 10949-10954.

Tang, Y., Perry, J.K., Jenden, P.D., Schoell, M., 2000. Mathematical modeling of stable carbon isotope ratios in natural gases. Geochim. Cosmochim. Acta 64, 2673-2687.

Taran, Y.A., 2005. A method for determination of the gas-water ratio in bubbling springs. Geophys. Res. Lett. 32, L23403. http://dx.doi.org/10.1029/ 2005GL024547.

Tassi, F., Fiebig, J., Vaselli, O., Nocentini, M., 2012. Origins of methane discharging from volcanic-hydrothermal, geothermal and cold emissions in Italy. Chem. Geol. 310-311, 36-48.

Tedesco, D., Allard, P., Sano, Y., Wakita, H., Pece, R., 1990. Helium-3 in subaerial and submarine fumaroles of Campi Flegrei caldera. Italy. Geochim. Cosmochim. Acta 54, 1105-1116.

Tedesco, D., 1997. Systematic variations of ${ }^{3} \mathrm{He} /{ }^{4} \mathrm{He}$ ratios and carbon of fumarolic fluids from active volcanic areas of Italy: evidence of radiogenic ${ }^{4} \mathrm{He}$ and crustal carbon addition by the subductiong African plate? Earth Planet. Sci. Lett. 151, 255-269.
Thode, H.G., 1991. Sulphur isotope in nature and the environment: an overview. In: Krouse, H.R., Grinenko, V.A. (Eds.), Stable Isotopes - Natural and Anthropogenic Sulphur in the Environment. Scope 43. Wiley, Chichester, pp. 1-23.

Vaselli, O., Tassi, F., Montegrossi, G., Capaccioni, B., Giannini, L., 2006. Sampling and analysis of volcanic gases. Acta Volcanol. 18, 65-76.

Whitfield, M., 1978. Activity coefficients in natural waters. In: Pytkowicz, R.M. (Ed.), Activity Coefficients in Electrolyte Solutions. CRC Press, Boca Raton, FL, pp. 153-300.

Whiticar, M.J., 1999. Carbon and hydrogen isotope systematics of bacterial formation and oxidation of methane. Chem. Geol. 161, 291-314.

Whiticar, M.J., Faber, E., Schoell, M., 1986. Biogenic methane formation in marine and freshwater environments: $\mathrm{CO}_{2}$ reduction vs. acetate fermentation - isotopic evidence. Geochim. Cosmochim. Acta 50, 693-709.

Worden, R.H., Smalley, P.C., 1996. $\mathrm{H}_{2}$ S-producing reactions in deep carbonate gas reservoirs: khuff Formation. Abu Dhabi. Chem. Geol. 133, 157-171.

Zhang, J., Quay, P.D., Wilbur, D.O., 1995. Carbon isotope fractionation during gaswater exchange and dissolution of $\mathrm{CO}_{2}$. Geochim. Cosmochim. Acta 82, 161-173.

Zuppi, G.M., Fontes, J.C., Letolle, R., 1974. Isotopes du milieu et circulation d'eaux sulfurées dans le Latium. In: Isotope Techniques in Groundwater Hydrology, vol. 1. IAEA, Vienna, pp. 341-361. 